\title{
Temporary Immersion System for Production of Biomass and Bioactive Compounds from Medicinal Plants
}

\author{
Anna De Carlo (D), Waed Tarraf*(D), Maurizio Lambardi and Carla Benelli \\ Institute of BioEconomy, National Research Council (CNR/IBE), Sesto Fiorentino, 50019 Florence, Italy; \\ anna.decarlo@ibe.cnr.it (A.D.C.); maurizio.lambardi@ibe.cnr.it (M.L.); carla.benelli@ibe.cnr.it (C.B.) \\ * Correspondence: waed.tarraf@ibe.cnr.it
}

Citation: De Carlo, A.; Tarraf, W.; Lambardi, M.; Benelli, C. Temporary Immersion System for Production of Biomass and Bioactive Compounds from Medicinal Plants. Agronomy 2021, 11, 2414. https://doi.org/ 10.3390 /agronomy11122414

Academic Editor: Sanja Cavar Zeljkovic

Received: 29 October 2021

Accepted: 25 November 2021

Published: 27 November 2021

Publisher's Note: MDPI stays neutral with regard to jurisdictional claims in published maps and institutional affiliations.

Copyright: (c) 2021 by the authors. Licensee MDPI, Basel, Switzerland. This article is an open access article distributed under the terms and conditions of the Creative Commons Attribution (CC BY) license (https:/ / creativecommons.org/licenses/by/ $4.0 /)$.

\begin{abstract}
The cultivation of medicinal plants and the production of bioactive compounds derived from them are of fundamental importance and interest, not only at the pharmacological level but also in nutraceutical and cosmetic industries and in functional foods, as well as plant protection in agriculture. In order to respond adequately to the increased demands of the global market from a quantitative and qualitative point of view and to guarantee environmental sustainability of the productions, it is necessary to resort to innovation tools, such as tissue culture in vitro technology. Nowadays, it is well known that the cultivation through the Temporary Immersion System (TIS) in a bioreactor has considerable advantages both for the in vitro mass production of the plants and for the production of secondary metabolites. The present review focuses on the application of TIS during the last two decades to produce biomass and bioactive compounds from medicinal plants. Indeed, almost one hundred papers are discussed, and they particularly focus on the effects of the culture system, vessel design and equipment, immersion time and frequency, and substrate composition for 88 medicinal species in TIS bioreactor culture.
\end{abstract}

Keywords: in vitro propagation; plant bioreactors; massive propagation; secondary metabolites; liquid culture; temporary immersion system

\section{Micropropagation of Medicinal Plants}

Tissues and organs of medicinal plants are a rich source of bioactive compounds, and plant-derived products can be used to improve food quality with healthy ingredients in the form of dietary supplements to contribute to a healthy diet by providing vitamins, antioxidants, and fibers (fortification). Almost $80 \%$ of the world's population employs plant-derived components for their health and wellness [1]. The different uses of medicinal plants together with the progress of scientific research allow for new perspectives and promote these species.

The term 'medicinal plant' has been extended in this review to include various uses such as herbal teas, spices, food, dietary supplements, and cosmetics, and it is widely accepted to avoid the narrow focus on modern pharmaceutical applications [2].

Biotechnological tools are important for a higher exploitation of the medicinal plants by adopting techniques such as in vitro regeneration and genetic transformation. In particular, biotechnology by means of tissue culture, cell biology, and molecular biology offers the opportunity to develop plants that are well adapted to changing climates and to meet the market demand [1,3]. In medicinal plants, in order to have standardized formulations the chemical constituents from plants and their parts are required to be uniform both qualitatively and quantitatively. For this reason, clonal mass multiplication is fundamental to yield small quantities of precious active compounds which are required in huge amounts [4].

When possible, medicinal plants should be grown under uniform environmental conditions and have the same genetic origin to ensure the stability of bioactive compounds 
and high yield, as in select clones. Frequently, in open field cultivation many medicinal plants show a low rate of seed germination or need special climatic conditions to germinate or take a long time to grow and multiply. Moreover, the productivity of many of these species is low due to the lack of high yielding, biotic stress-tolerant cultivars and the absence of disease-free materials of elite genotypes [5]. Consequently, there is an urgency to preserve and propagate such species for future uses by adopting and improving efficient mass propagation techniques. These goals can be achieved through an in vitro strategy with well-defined protocols and appropriate methods that increase the production of biomass and specific important secondary metabolites. Furthermore, the in vitro propagation technique represents a valid alternative to the collection of resources in the natural environment, preventing the threat of extinction to which many medicinal plants are subjected. Micropropagation of many medicinal plants has been described by various authors since the $1880 \mathrm{~s}[3,6,7]$. In the last 20 years in particular, numerous papers have been produced reporting the optimization of micropropagation protocols for medicinal species, mainly the threatened plant species [4,8-10]. The micropropagation of medicinal plants is a tool for producing plants with high-yielding chemotypes for cultivation and industrial purposes, and thus it allows for production of biomass with genetically identical chemotypes and select plants based on the chemical profile in order to standardize a particular chemotype [11]. Finally, micropropagation is useful for reducing consumption pressure on potentially threatened wild populations [11,12].

The propagation of medicinal plants through tissue culture occurs with the typical methods used for other plants. The most common approaches are (i) to isolate organized meristems, like shoot tips or axillary buds, and induce them to grow into complete plants (micropropagation), and (ii) by adventitious shoots from leaf, root, and stem segments or calluses derived from those organs. The last system of propagation involves induction of somatic embryogenesis in cell and callus cultures [3]. Moreover, in vitro tissue culture of medicinal plants is used to produce active compounds for herbal and pharmaceutical industries [13]. The use of medicinal plants in vitro cultures is focused on the production of valuable bioactive compounds $[4,14,15]$ which can be defined as secondary plant metabolites such as pharmaceuticals, flavors, and fragrances. Some metabolites are present in all plants, while others are synthesized in specific species or tissues and sometimes in response to external stimuli.

Large-scale use of plant tissue culture can be an interesting alternative approach to traditional methods of cultivation as it offers a controlled yield and supply of biochemicals independent of plant season availability, resulting in higher production and more consistent quality.

Sometimes the limits to large-scale production are related to the species and others depend on the cost of propagation. Micropropagation by conventional technique is a labor-intensive system of clonal propagation and the automation in bioreactor of micropropagation can be a possible tool for reducing its costs ([14,16-19]. Practically, plant culture bioreactors can be divided into two principal types: bioreactors in which the cultures are continuously submerged in the liquid medium and, more innovatively, those in which the cultures are periodically immersed following specific cycles of time (i.e., temporarily). Hence, this paper focuses on the Temporary Immersion System (TIS) for an overview of its application in medicinal plants during the last 20 years.

\section{TIS Bioreactors for Micropropagation of Medicinal Plants}

The bioreactor is a simple piece of equipment consisting of a culture vessel and a fully automated or semi-automated control system, often with air inflow and outflow systems, designed for intensive culture with the opportunity for monitoring and control of microenvironmental culture conditions. All plant bioreactors use liquid media, either in continuous or in a temporary immersion culture, and this condition offers the best situation for efficient large-scale plant in vitro propagation [20,21]. Indeed, liquid culture systems can provide much more uniform culturing conditions, easy renewal of the media without 
changing the container, the possibility of sterilization using microfiltration, and easier cleaning of the container after the culture period.

The production of plant species using a liquid medium in bioreactors is a complementary strategy in order to overcome the limitations present in the in vitro system on conventional semi-solid media. In comparison with culturing on semi-solid media, larger containers can be used, and transfer times can be reduced to avoid intensive manual handling. The bioreactors developed in the past were not suitable for plants micropropagation, they were mainly developed for bacterial culture and did not consider the specific requirements of the plant, such as mechanical damage and foam formation in bubble aerated bioreactors.

The first report on the use of a plant bioreactor in continuous liquid culture for micropropagation was by Takayama and Misawa for Begonia [22]. Sometimes, however, the total permanent immersion of explants into the liquid medium can cause malformations and loss of material due to asphyxia and hyperhydricity [23]. These undesirable physiological conditions are mainly caused by low oxygen rates and water potential of the culture media [23-25].

A TIS bioreactor using the periodical contact between the plants and the liquid medium can be a tool to overcome these difficulties and encourages the development and adaptation of plants to the next stage of acclimatization [26]. This system is based on alternating cycles of temporary immersion of the cultured plant tissue into the liquid medium followed by a dry period. Generally, the immersion period is short (a few minutes), while the dry period is extended (several hours). TIS bioreactors are usually made with transparent glass or plastic vessels, allowing the light from external sources to illuminate the cultivated plant materials. Harris and Mason [27] described for the first time a device that could be reclined to realize temporary immersion in order to combine aeration and liquid medium culture. Various types of TIS bioreactors for plants have been realized, many of them custom-made [28], but currently different TIS models are available on the market consisting of one container (Figure 1) or two containers (Figure 2), and are sometimes equipped for gas exchange by ventilation phases. Detailed descriptions of some plant TIS bioreactors are reported by Georgiev et al. [29], or available on the websites of production companies (e.g., https://setis-systems.be (accessed on 20 November 2021); http:/ /www.plantform.se (accessed on 20 November 2021); http:/ / www.bioreactor-matis.com (accessed on 20 November 2021). The liquid culture in TIS has already been successfully used in the micropropagation of several economically important species, among which are woody plants and ornamental plants [30-33].

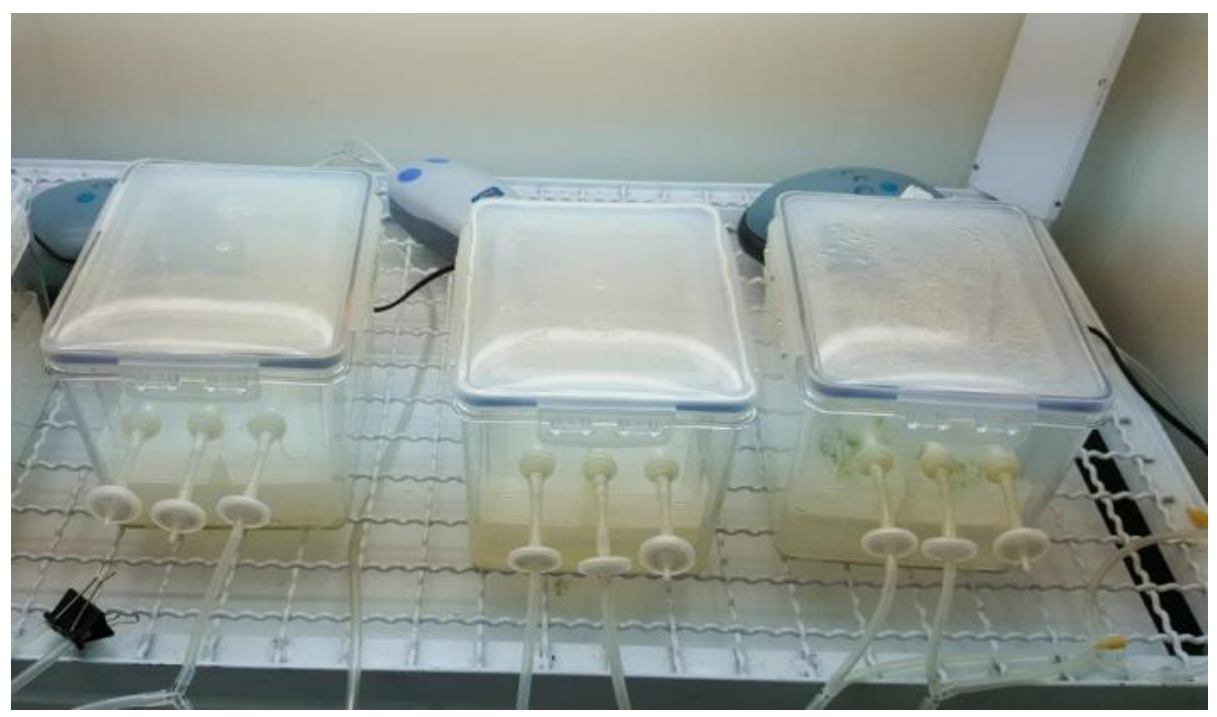

Figure 1. PlantForm bioreactor TIS model consisting of one container. 


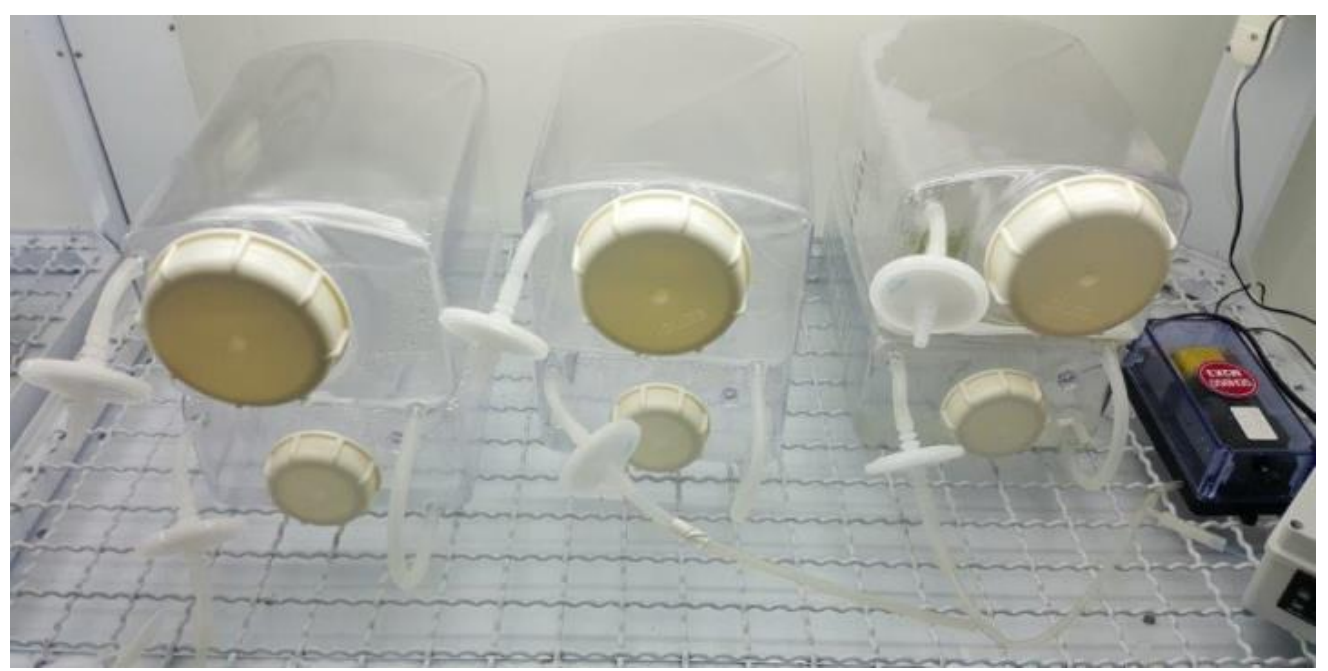

Figure 2. SETIS bioreactor TIS model consisting of two containers.

TIS allows for various advantages: (I) a more uniform contact between the culture medium and the plant material in comparison to the conventional culture in semi-solid medium, (II) the reduction of asphyxia and hyperhydricity of cultured tissues, (III) the dilution of toxic compounds (e.g., phenols) released by the plants, producing culture oxidation and browning, (IV) the periodic replacement of the atmosphere within the culture container, which limits gas accumulation (mainly $\mathrm{CO}_{2}$ and ethylene), a typical event which occurs when working with the traditional gas-tight glass jars, (IV) the possibility to extend consistently the subculture time when using large containers, and (V) the possibility to markedly reduce hand labor and cost of production, as a careful positioning of explants in the gelled medium is not necessary and the refill of the fresh liquid medium is done easily.

To develop in vitro plants, the availability of macro- and micronutrients during the culture in bioreactors is essential, influencing both the development and the secondary metabolism production [34]. The optimization of the medium culture (nutrients, carbohydrates, growth regulators) and the control and monitoring of different parameters such as immersion time, temperature, light quality, and aeration, can contribute to producing large amounts of biomass with an increase in the accumulation of secondary metabolites. Moreover, the changing of the immersion program could be used to manipulate the metabolic processes of the in vitro plants, depending on the primary goal of micropropagation or accumulation of specific secondary metabolites [35]. In particular, the precise adjustment of the immersion time and dry periods may significantly reduce the hyperhydricity of the plant tissue, creating conditions for optimal humidity and nutrients supply, a better control of plant morphogenesis, and consequently good biomass [30] and secondary metabolite production. Hyperhydricity is one of the primary factors limiting the liquid culture efficiency, with evident morphological malformation in the cultured plants, such as shorter internodes and brittle, translucent, and wrinkled leaves [36-39].

Overall, the development of medicinal plant production is a key factor for obtaining a commercial source of medicinal biomass for the pharmaceutical industry. In fact, non-stable supply sources can be a bottleneck that limits these beneficial products. For example, fundamental research on anti-cancer pharmaceutical compounds obtained from Taxus baccata are restricted to insufficiency in the biomass production and this leads to overharvesting of the natural resources: indeed, the production of $1 \mathrm{~kg}$ of taxol needs to collect around 10,000 kg of dry bark of Taxus sp. [40]. The advantage of using the TIS in micropropagation comes from the possibility to respond to the high demand of producing plant biomass [41]. TIS is also skilled for secondary metabolite production by differentiated plant tissues and organs [29,30], and it is especially interesting in the medicinal plant sector $[21,35,42]$. The phytochemicals biosynthesized by the pathways of secondary 
metabolism are very important and are required in the pharmaceutical, food, cosmetic, and other industries. The quantity and quality of these bioactive compounds from cultivated or natural plants fluctuate with their composition varies, and for this reason the production by in vitro approaches, in controlled conditions, offers a great prospect. The application of the tissue culture approach for production of secondary metabolites of pharmaceutical importance (particularly alkaloids, steroids, and terpenes) on a commercial scale has been increasing year by year [1]. Despite the growing market of plant metabolites, only a few of them are produced in bioreactors at a commercial scale; the product of the bioreactor unit is the biomass, which then goes through the extraction unit for separation and purification of the target metabolite. The first report on the use of TIS bioreactor for secondary metabolites production was by Schmeda-Hirschmann et al. [43] on Fabiana imbricata.

\section{Use of TIS in Medicinal Plants for the Production of Biomass and Bioactive Compounds from 2000 to Today}

The present contribution focuses attention on the application of TIS to medicinal plants over the last 20 years. A bibliometric search showed that during the first decade the average of papers on this topic was low (1.5 papers/year), while in the second decade the number increased four-fold (six papers/year). All the reported papers in this review are divided into two groups based on the final purpose: production of biomass (Table 1) or the accumulation of secondary metabolites (Table 2). Fifty-three species of medicinal plants were propagated with TIS for biomass production, while thirty-six species were considered to obtain specific plant metabolites.

Table 1. Biomass production in medicinal plants cultured in TIS with different bioreactors and immersion times. Best results are reported for each species (terminology and values are the same as mentioned by the authors).

\begin{tabular}{|c|c|c|c|c|}
\hline Species & Bioreactor * & $\begin{array}{l}\text { Immersion Frequency } \\
\text { (Immersion/Dry) }\end{array}$ & $\begin{array}{c}\text { Biomass in TIS } \\
\text { (vs. Semi-Solid Culture System) }\end{array}$ & Reference \\
\hline $\begin{array}{l}\text { Anoectochilus } \\
\text { formosanus }\end{array}$ & Ebb and Flood & $30 \mathrm{~min} / 6 \mathrm{~h}$ & $\begin{array}{c}\text { Fresh biomass }(\mathrm{g} / \mathrm{L}): \sim 100 \\
\text { (919.2 in continuous immersion) }\end{array}$ & {$[44]$} \\
\hline \multirow{3}{*}{ Anthurium andreanum } & RITA & $3 \mathrm{~min} / 3 \mathrm{~h}$ & Multiplication rate: 5.17 & [45] \\
\hline & TIB & $2 \mathrm{~min} / 12 \mathrm{~h}$ & $\begin{array}{c}\text { No. shoots/explant: } 50.83 \\
\text { FW (g): } 0.61 \\
\text { DW (g): } 0.031 \mathrm{~g}\end{array}$ & [46] \\
\hline & Ebb and Flow & $2 \mathrm{~min} / 4 \mathrm{~h}$ & No. shoots/explant: 31.50 (4.50) & [47] \\
\hline Aquilaria malaccensis & RITA & $15 \mathrm{~min} / 4 \mathrm{~h}$ & $\begin{array}{c}\text { Shoots / initial explant: } 5.12 \\
\text { (2.14 in continuous immersion) } \\
\text { FW (g): } 3.12 \text {, increases of about } \\
1.8 \text {-fold }\end{array}$ & [48] \\
\hline Aristotelia chilensis & Two Vessels & $4 \mathrm{~min} / 6 \mathrm{~h}$ & $\begin{array}{c}\text { Multiplication rate: } 6.38 \\
\text { FW (mg) per cluster: } 37.42\end{array}$ & [49] \\
\hline Artemisia judaica & RITA & $3 \mathrm{~min} / 3 \mathrm{~h}$ & $\begin{array}{c}\text { Multiplication rate: } 65 \\
\text { (35 in continuous immersion) }\end{array}$ & {$[50]$} \\
\hline Bambusa vulgaris & Twin Flasks & $2 \mathrm{~min} / 6 \mathrm{~h}$ & No. shoots/explant: 13.05 & {$[51]$} \\
\hline Bletilla striata & BioF-V & $3 \mathrm{~min} / 6 \mathrm{~h}$ & not reported & {$[52]$} \\
\hline Calathea orbifolia & Plantima & $2 \mathrm{~min} / 3 \mathrm{~h}$ & FW (g): $13.8(8.2)$ & [53] \\
\hline Capparis spinosa & PlantForm & $2 \mathrm{~min} / 12 \mathrm{~h}$ & $\begin{array}{c}\text { RGR (mg/g d): } 7.89(0.84) \\
\text { No. shoots/explant: } 7.32(5.24)\end{array}$ & {$[54]$} \\
\hline Cattleya walkeriana & BIT & $3 \mathrm{~min} / 90 \mathrm{~min}$ & $\begin{array}{c}\text { FW (g): } 0.32(0.24) \\
\text { DW (g): } 0.032(0.008)\end{array}$ & [55] \\
\hline Charybdis numidica & Two Bottles & $5 \mathrm{~min} / 12 \mathrm{~h}$ & Shoot per gram inoculum: 36.6 (194.2) & [56] \\
\hline Colocasia esculenta & SETIS & $2 \mathrm{~min} / 4 \mathrm{~h}$ & Multiplication rate: $36(6.10)$ & [57] \\
\hline
\end{tabular}


Table 1. Cont.

\begin{tabular}{|c|c|c|c|c|}
\hline Species & Bioreactor * & $\begin{array}{l}\text { Immersion Frequency } \\
\text { (Immersion/Dry) }\end{array}$ & $\begin{array}{c}\text { Biomass in TIS } \\
\text { (vs. Semi-Solid Culture System) ** }\end{array}$ & Reference \\
\hline Crescentia cujete & RITA & $3 \mathrm{~min} / 3 \mathrm{~h}$ & FW (mg): 950 (200) & [58] \\
\hline \multirow{2}{*}{ Cymbopogon citratus } & Two Flasks & 6 immersions $/ 24 \mathrm{~h}$ & $\begin{array}{l}\text { Multiplication coefficient: } 12.3 \text { (4.8) } \\
\text { FW (g): } 66.2(10.1)\end{array}$ & [59] \\
\hline & RITA & $1 \mathrm{~min} / 4 \mathrm{~h}$ & not reported & {$[60]$} \\
\hline Curcuma longa & Two Flasks & $4 \mathrm{~min} / 4 \mathrm{~h}$ & Proliferation rate: 4.2 & [61] \\
\hline Curcuma zedoaria & $\begin{array}{l}\text { Nalgene }{ }^{\circledR} \text { filtration } \\
\text { system }\end{array}$ & $15 \mathrm{~min} / 24 \mathrm{~h}$ & $\begin{array}{c}\text { No. shoots/explant: } 5(3) \\
\text { FW (g): } 4.91 \text { (9.94 in continuous) }\end{array}$ & {$[62]$} \\
\hline \multirow{2}{*}{ Dianthus caryophyllus } & Two Containers & $2 \mathrm{~min} / 6 \mathrm{~h}$ & No. new shoots: 14.33 (5.7) & [63] \\
\hline & RITA & $90 \mathrm{~s} / 8 \mathrm{~h}$ & No. shoots/plantlet: 2.0 (1.3) & {$[64]$} \\
\hline \multirow[t]{2}{*}{ Digitalis purpurea } & Two Bottles & $2 \mathrm{~min} / 4 \mathrm{~h}$ & $\begin{array}{c}\text { FW }(\mathrm{g}): 104.03 \\
\text { DW }(\mathrm{g}): 5.74\end{array}$ & [65] \\
\hline & Vessels & $2 \mathrm{~min} / 4 \mathrm{~h}$ & not reported & [66] \\
\hline Dioscorea fordii & Plantima & $3 \mathrm{~min} / 4 \mathrm{~h}$ & $\begin{array}{l}\text { Proliferation rate: } 5.0(2.4) \\
\text { FW (mg): } 423.3(72.2) \\
\text { DW }(\mathrm{mg}): 39.4(6.3)\end{array}$ & [67] \\
\hline Echinacea angustifolia & RITA & not reported & Multiplication rate: highest in RITA & {$[68]$} \\
\hline Epipactis flava & Twin Bottles & $5 \mathrm{~min} / 4 \mathrm{~h}$ & No. shoots/explant: $1.5(1.0)$ & [69] \\
\hline $\begin{array}{l}\text { Eucalyptus grandis } \times \\
\text { E. urophylla }\end{array}$ & TIB & $30 \mathrm{~s} / 3 \mathrm{~h}$ & No. shoots/explant: 8 & {$[70]$} \\
\hline Eurycoma longifolia & RITA & $5 \mathrm{~min} / 4 \mathrm{~h}$ & Multiplication rate: 69.6 (26.6) & [71] \\
\hline Glycyrrhiza glabra & Twin Flasks & $5 \mathrm{~min} / 4 \mathrm{~h}$ & Multiplication rate: 9.47 (6.16) & {$[72]$} \\
\hline Gynura procumbens & BIT & $15 \mathrm{~min} / 12 \mathrm{~h}$ & FW (g): 10.24 & [73] \\
\hline Helichrysum italicum & Twin Flasks & $5 \mathrm{~min} / 24 \mathrm{~h}$ & Multiplication rate: 16.4 (11.6) & [72] \\
\hline Hevea brasiliensis & RITA & $1 \mathrm{~min} / 24 \mathrm{~h}$ & RGR: $0.084(0.085)$ & {$[74]$} \\
\hline Hippeastrum $\times$ chmielii & Twin Flasks & $32 \mathrm{~min} / 24 \mathrm{~h}$ & Propagation rate: $6.44(3.85)$ & [75] \\
\hline Hypericum perforatum & TI Bioreactor & $\begin{array}{l}5 \mathrm{~min} / 3 \mathrm{~h} \text { for } 15 \text { days } \\
\text { and then } 5 \mathrm{~min} / 24 \mathrm{~h}\end{array}$ & $\begin{array}{l}\text { No. regenerants/explants: } 209 \text { (106, in } \\
\text { continuous immersion) }\end{array}$ & [41] \\
\hline Hypoxis argentea & PlantForm & $6 \mathrm{~min} / 12 \mathrm{~h}$ & No. shoots/explant: 12 & [76] \\
\hline Jacaranda decurrens & RITA & $15 \mathrm{~min} / 4 \mathrm{~h}$ & Multiplication rate: 9.61 & [77] \\
\hline Jeffersonia dubia & Plantima & $30 \mathrm{~s} / 30 \mathrm{~min}$ & No. shoots/explant: 13.6 (7.3) & [78] \\
\hline $\begin{array}{l}\text { Lessertia (Sutherlandia) } \\
\quad \text { frutescens }\end{array}$ & BTBB & $30 \mathrm{~min} / 4 \mathrm{~h}$ & $\begin{array}{l}\text { Shoot multiplication: } 12.9(7.8) \\
\text { FW (mg): } 3109 \text { (104.2) } \\
\text { DW (mg): } 351.8(10.3)\end{array}$ & [79] \\
\hline Leucojum aestivum & RITA & $5 \mathrm{~min} / 2 \mathrm{~h}$ & No. bulbs (\%): 74.6 (71.7) & [80] \\
\hline Morinda royoc & TIS Bioreactor & $2 \mathrm{~min} / 4 \mathrm{~h}$ & Multiplication coefficient: 6.0 & [81] \\
\hline \multirow[b]{2}{*}{ Myrtus communis } & PlantForm & $8 \mathrm{~min} / 16 \mathrm{~h}$ & RGR: 6.2 (5.3) & [82] \\
\hline & PlantForm & $15 \mathrm{~min} / 8 \mathrm{~h}$ & $\begin{array}{c}\text { Micropropagation rate: } 11.40(6.25) \\
\text { FW (g): } 1.00(0.17) \\
\text { DW (g): } 0.26(0.02)\end{array}$ & [83] \\
\hline Olea europaea & PlantForm & $8 \mathrm{~min} / 16 \mathrm{~h}$ & No. shoots/explant: $0.77(0.36)$ & [84] \\
\hline Picea abies & PlantForm & $20 \mathrm{~min} / 4 \mathrm{~h}$ & $\begin{array}{l}\text { Embryo production per g } \\
\text { pro-embryogenic mass: } 696(174)\end{array}$ & [85] \\
\hline Picrorhiza kurroa & Twin Flasks & $5 \mathrm{~min} / 8 \mathrm{~h}$ & Multiplication rate: $8.20(4.68)$ & [72] \\
\hline
\end{tabular}


Table 1. Cont.

\begin{tabular}{|c|c|c|c|c|}
\hline Species & Bioreactor * & $\begin{array}{l}\text { Immersion Frequency } \\
\text { (Immersion/Dry) }\end{array}$ & $\begin{array}{c}\text { Biomass in TIS } \\
\text { (vs. Semi-Solid Culture System) ** }\end{array}$ & Reference \\
\hline Pinellia ternata & not reported & not reported & No. tubers/plantlet: 24.73 (14.75) & [86] \\
\hline Piper aduncum & RITA & $3 \mathrm{~min} / 6 \mathrm{~h}$ & $\begin{array}{l}\text { Germination of somatic embryos (\%): } \\
100(100)\end{array}$ & [87] \\
\hline Pistacia lentiscus & RITA & $3 \mathrm{~h} / 24 \mathrm{~h}$ & No. shoot/explant: 6.18 (5.8) & [88] \\
\hline Psidium guajava & RITA & $2 \mathrm{~min} / 6 \mathrm{~h}$ & $\begin{array}{l}\text { Multiplication coeff.: } 4.90(4.36) \\
\text { No. shoots: } 2.17(1.78)\end{array}$ & [89] \\
\hline Quercus robur & PlantForm & $8 \mathrm{~min} / 16 \mathrm{~h}$ & $\begin{array}{c}\text { RGR: } 6(4) \\
\text { No. shoots/explant: } 3 \text { (2.5) }\end{array}$ & [90] \\
\hline Rhodiola rosea & RITA & $15 \mathrm{~min} / 4 \mathrm{~h}$ & No. shoots/explant: 16 & [91] \\
\hline Saponaria officinalis & Twin Flasks & $5 \mathrm{~min} / 8 \mathrm{~h}$ & Multiplication rate: 4.36 (2.39) & [72] \\
\hline Siraitia grosvenorii & Plantima & $4 \mathrm{~min} / 4 \mathrm{~h}$ & $\begin{array}{c}\text { Proliferation rate: } 8.75(3.72) \\
\text { FW (mg): } 501.25(168.89) \\
\text { DW (mg): } 60.83(21.94)\end{array}$ & [92] \\
\hline \multirow{5}{*}{ Stevia rebaudiana } & BIT & $10 \mathrm{~min} / 12 \mathrm{~h}$ & $\begin{array}{l}\text { FW (mg): } 774.39 \\
\text { DW (mg): } 83.41\end{array}$ & [93] \\
\hline & $\begin{array}{c}\text { RITA } \\
\text { PlantForm }\end{array}$ & $\begin{array}{l}3 \mathrm{~min} / 3 \mathrm{~h} \\
3 \mathrm{~min} / 8 \mathrm{~h}\end{array}$ & No. shoots/explants: 14 & [94] \\
\hline & RITA & $2 \mathrm{~min} / 4 \mathrm{~h}$ & No. shoots/explant: 11.8 (4.6) & [95] \\
\hline & BIT & $2 \mathrm{~min} / 12 \mathrm{~h}$ & Multiplication rate: 8 shoots/plant & [96] \\
\hline & RITA & $10 \mathrm{~s} / 1 \mathrm{~h}$ & No. shoots/explant: 8.47 (2.00) & [97] \\
\hline Swertia chirayita & Twin Flasks & not reported & No. shoots/explants: 28 & [98] \\
\hline Tropaeolum tuberosum & RITA & $2 \mathrm{~min} / 3 \mathrm{~h}$ & $\begin{array}{l}\text { Microtubers quantity: } 56 \\
\text { Weight of microtubers }(\mathrm{g}): 0.2 \\
\text { Size of microtuber }(\mathrm{cm}): 1.9\end{array}$ & [99] \\
\hline Tussilago farfara & Two Flasks & $5 \mathrm{~min} / 8 \mathrm{~h}$ & Multiplication rate: 5.65 (4.15) & [72] \\
\hline Vaccinium corymbosum & Two Vessels & $3 \mathrm{~min} / 6$ or $8 \mathrm{~h}$ & Multiplication rate: 26.2 (12.7) & [100] \\
\hline \multirow{5}{*}{ Vanilla planifolia } & $\mathrm{BIT}$ & $2 \mathrm{~min} / 4 \mathrm{~h}$ & $\begin{array}{c}\text { No. shoots/explants: } 18.06 \\
\text { FW (g): } 6.02 \\
\text { DW (g): } 0.41\end{array}$ & [95] \\
\hline & TIB & $2 \mathrm{~min} / 8 \mathrm{~h}$ & No. shoots/plantlet: 9.15 (1.3) & [46] \\
\hline & RITA & $2 \mathrm{~min} / 4 \mathrm{~h}$ & Multiplication rate: 14.27 (5.80) & [101] \\
\hline & RITA & $2 \mathrm{~min} / 6 \mathrm{~h}$ & $\begin{array}{c}\text { No. shoots/explant: } 14.89 \\
\text { FW (g): } 5829.00 \\
\text { DW (g): } 447.20\end{array}$ & [102] \\
\hline & SETIS & $2 \mathrm{~min} / 4 \mathrm{~h}$ & $\begin{array}{c}\text { No. shoots/explant: } 11.41(3.76) \\
\text { FW (g): } 6.65(1.71) \\
\text { DW (g): } 0.42(0.15)\end{array}$ & [103] \\
\hline Zingiber zerumbet & $\begin{array}{l}\text { Nalgene }{ }^{\circledR} \text { filtration } \\
\text { system }\end{array}$ & $15 \mathrm{~min} / 24 \mathrm{~h}$ & $\begin{array}{c}\text { No. shoots/explant: } 4 \text { (3) } \\
\text { FW (g): } 2.31 \text { (9.94 in continuous } \\
\text { immersion) }\end{array}$ & [62] \\
\hline
\end{tabular}

* Different names of Twin Flasks (two vessels, two bottles, two containers, twin bottles) refer essentially to analogous TIS systems. ** Values between parentheses refer to the semi-solid culture, if not differently specified. FW: fresh weight, DW: dry weight, BioF-V: TIS bioreactor from Biofunction Co. Ltd. (Nanjing, China), RGR: Relative Growth Rate, Plantima: TIS bioreactor from A-Tech Bioscientific Co., Ltd. (Taipei, Taiwan), BTBB: balloon-type bubble bioreactors.

The effects of the culture system, vessel design, equipment, immersion time and frequency, and substrate composition were investigated. It should be noted that in the examined papers the values were not always consistent with each other; for example, the 
biomass can be expressed as the number of shoots per explant, fresh or dry weight, or multiplication rate. Therefore, the values of biomass production in Table 1 and of bioactive compounds in Table 2 are compared with the values obtained in semi-solid medium; if not available, the culture system used for the comparison is reported.

\subsection{Culture System}

In the literature, the TIS guarantees better nutrients and Plant Growth Regulators (PGRs) uptake, as well as higher daily air exchange in comparison to semi-solid culture media [104]. Therefore, several studies evaluated the effectiveness of TIS and other culture systems on achieving the maximal biomass production (Table 1) and optimizing the accumulation of bioactive compounds (Table 2).

\subsubsection{Culture System and Biomass Production}

Some species have adapted very well to propagation in TIS compared to culture on semi-solid medium, such as Dianthus caryophyllus, which recorded an average of 3.0 shoots per plantlet instead of 1.3 and fresh weight (FW) at least 3 times greater (with frequency immersion of $90 \mathrm{~s} / 8 \mathrm{~h}$ ) than conventional culture in semi-solid medium [64].

Pistacia lentiscus, Stevia rebaudiana, and Vanilla plantifolia showed a significantly improved multiplication rate when grown in TIS compared to conventional semi-solid culture system $[88,95,101]$. In particular, shoots of Vanilla plantifolia produced the maximum multiplication rate (14.27 shoots per explant) when using TIS, with an immersion frequency of 2 min every 4 h, i.e., 2.5 times higher than the multiplication rate on semi-solid medium (5.80 shoots for explant). Interestingly, Crescentia cujete inoculated in a TIS bioreactor had a higher significant fresh and dry weight than those in semi-solid and flask-liquid culture [58].

It was possible to promote the growth and quality of Siraitia grosvenorii and Dioscorea fordii plantlets by TIS, which reported a greater proliferation rate, FW, and dry weight (DW), while in semi-solid and liquid the medium decreased [67,92]. Morinda royoc [81] and Psidium guajava [89] explants growth in TIS recorded the highest values of multiplication coefficient and number of shoots with maximal biomass compared with semi-solid culture.

The efficiency of TIS was noted when a considerable increase in multiplication rate was observed in Echinacea angustifolia [68] and Jacaranda decurrens [77]. For the micropropagation of blueberry plants, a promised approach mediated by TIS doubled the multiplication rate values compared to agar-base medium [100]. Similarly, TIS in Vanilla planifolia maximized the multiplication rate (14.27 shoots vs. 5.80 in semi-solid) [101], the FW (6.65 g vs. 1.71 in semi-solid), the DW (0.42 g vs. 0.15 in semi-solid) [103], as well as in Anthurium andreanum the shoot number (31.50) per plant [47], with respect to the partial immersion system (7.25), where about $5 \mathrm{~mm}$ of the shoot base was submerged in liquid medium and semi-solid medium (4.50).

The comparison of three different culture systems showed the prevalence of TIS over conventional semi-solid and liquid continuous immersion to induce the highest shoot number (1.5) of Epipactis flava [69] and to obtain the largest FW (3109.0 g) and DW (351.8 g) of Lessertia frutescens [79]. In addition, the application of TIS treatments on Hippeastrum $\times$ chmielii yielded greater propagation rates (6.44) than semi-solid medium (3.85) [75]. Aka Kaçar et al. [83] referred to TIS as a valid alternative to traditional in vitro micropropagation of myrtle, resulting in plantlets successfully growing better than those in semi-solid medium in terms of FW and DW.

Olea europaea, an important species for the Mediterranean countries, was tested under TIS conditions. Indeed, an efficient proliferation of shoots was reported per explant (0.77), whereas it was reduced to 0.36 shoots in the semi-solid culture [84]. To scale up the production of Picea abies, a 2.5-fold increase in the pro-embryogenic mass was achieved in the TIS bioreactor compared to semi-solid medium [85]. The micropropagation of Pinellia ternata was improved using the temporary immersion bioreactor, as it showed a high potential to induce the largest number of tubers per plantlet compared to solid and 
liquid culture [86]. On the other hand, no difference between the semi-solid medium and TIS was noted for Quercus robur production with respect to the shoot number per explant. Yoon et al. [44] revealed that biomass production from Anoectochilus formosanus was less efficient when culturing was performed under temporary immersion. In a recent study on in vitro multiplication of Colocasia esculenta, applying different culture systems demonstrated that the highest regeneration rate was with TIS [57].

\subsubsection{Culture System and Bioactive Compounds Content}

To meet the increasing market demand for rapid propagation of plant material and then a stable supply of secondary metabolites, many studies based on in vitro culture methods have been performed to improve the production of specific plant-derived chemicals.

Plants from Arnica montana showed higher sesquiterpene lactones content $(15.34 \mathrm{mg} / \mathrm{g} \mathrm{DW})$ in TIS than those from the semi-solid medium $(7.62 \mathrm{mg} / \mathrm{g} \mathrm{DW})$ and static liquid medium (13.81 mg/g DW) [105]. The level of camptothecin (2.5 mg/g DW) of Camptotheca acuminata grown in TIS was comparable to the semi-solid culture [106]. In contrast, plumbagin, as the main bioactive compound from Drosera communis, was reduced in its yield by TIS compared to the semi-solid system and continuous immersion system [69]. Shoots of Lycium barbarum propagated in TIS were characterized by high concentration of total phenolic (23.6 mg gallic acid equivalent-GAE/g DW) and low flavonoid content (1.9 mg rutin equivalent-RE/g DW) compared to semi-solid culture [107]. The effect of TIS on the growth, development, quality, and biochemical characteristics of different rose species was investigated by Malik et al. [108], showing that Rosa tomentosa and Rosa rubiginosa plants propagated in TIS were characterized by a high content of phenolic compounds, soluble sugars, and multiplication rate, and were better than those of plants developed on semi-solid culture.

Interestingly, the contents of major bioactive compounds in Hypericum perforatum (Hypericin, $0.18 \mathrm{mg} / \mathrm{g}$ DW), Cymbopogon citratus ( $\alpha$-citral, $0.35 \mathrm{mg} / \mathrm{g}$ DW and $\beta$-citral, $0.54 \mathrm{mg} / \mathrm{g}$ DW), and Fabiana imbricata (oleanolic acid, $0.01 \mathrm{mg} / \mathrm{g} \mathrm{DW}$ ) were considerable in plant material grown in TIS compared to cell suspension and callus cultures [109]. Since flavonoids are the principal active constituents of Scutellaria baicalensis, six culture systems were compared to optimize the phytochemical content in plant tissues. Indeed, TIS was effective in providing significantly higher baicalein and baicalin concentration than the other systems [110]. Vives et al. [111] showed a considerable increase in the formation of steviol glycosides $(0.12 \mathrm{~g})$ as natural sweeteners from Stevia rebaudiana shoots in TIS compared to liquid $(0.02 \mathrm{~g})$ and semi-solid $(0.03 \mathrm{~g})$ culture medium.

TIS promoted the contents of carotenoid $(0.40 \mu \mathrm{g} / \mathrm{mL})$ in wild Vaccinium vitis-idaea ssp. Minus more than shoots micro-propagated in stationary bioreactor [112]. Adventitious roots of Catharanthus roseus grown in the temporary immersion bioreactor offered high ajmalicine content [113]. In vitro cultures of Harpagophytum procumbens, the plants grown using TIS accumulated total iridoids, particularly harpagoside and its concentration in the leaves, were significantly greater than the control treatment [114].

It was possible to scale up the production of Rhododendron tomentosum using various liquid systems to improve the accumulation of bioactive volatile fractions. The highest essential oil content and its terpenoid compounds, mainly $p$-cymene, alloaromadendrene, shyobunone, and ledene oxide II, were obtained by means of TIS [115]. Mišić et al. [116] hypothesized that higher biomass and metabolites in hair roots of Centaurium maritimum were obtained in TIS bioreactors as result of high $\mathrm{O}_{2}$ transfer rates, reduced shear and hydrodynamic forces, better nutrient availability, and avoidance of hyperhydricity phenomena. 
Table 2. Bioactive compounds production in medicinal plants cultured in TIS with different bioreactors and immersion times. Best results are reported for each species (terminology and values are the same as mentioned by the authors).

\begin{tabular}{|c|c|c|c|c|}
\hline Species & Bioreactor * & $\begin{array}{l}\text { Immersion Frequency } \\
\text { (Immersion/Dry) }\end{array}$ & $\begin{array}{l}\text { Bioactive Compound in TIS } \\
\text { (vs. Semi Solid Culture System) ** }\end{array}$ & Reference \\
\hline Arnica montana & RITA & $5 \mathrm{~min} / 6 \mathrm{~h}$ & $\begin{array}{l}\text { Sesquiterpene lactones (mg/g DW): } \\
15.34(7.62)\end{array}$ & [105] \\
\hline Aristotelia chilensis & Two Vessels & $4 \mathrm{~min} / 6 \mathrm{~h}$ & $\begin{array}{l}\text { Total phenols (g GAE/100 g DW): } 2.97 \\
\text { (3.04 in wild plants) }\end{array}$ & {$[49]$} \\
\hline Beta vulgaris & RITA & $15 \mathrm{~min} / 1 \mathrm{~h}$ & $\begin{array}{c}\text { Betalains (mg/g DW): } 18.8 \\
\text { Betacyanins (mg/g DW): } 9.6 \\
\text { Betaxanthins (mg/g DW): } 9.2\end{array}$ & [117] \\
\hline Camptotheca acuminata & DVS, RITA & $1 \mathrm{~min} / 3 \mathrm{~h}$ & Camptothecin (mg/g DW): 2.5 (2.2) & [106] \\
\hline \multirow[b]{2}{*}{ Castilleja tenuiflora } & RITA & $30 \mathrm{~min} / 24 \mathrm{~h}$ & $\begin{array}{l}\text { Total phenolics (mg GAE/g DW): } 30.58 \\
\text { Total flavonoid ( } \mu \mathrm{g} \text { CE/g DW): } 45.83\end{array}$ & [118] \\
\hline & RITA & $5 \mathrm{~min} / 24 \mathrm{~h}$ & $\begin{array}{c}\text { Total phenolics (mg GAE/g DW): } 41.3 \\
\text { Verbascoside (mg/g DW): } 113.9 \\
\text { Isoverbascoside (mg/g DW): } 36.4\end{array}$ & [119] \\
\hline Catharanthus roseus & Bottles & $5 \mathrm{~min} / 3 \mathrm{~h}$ & Ajmalicine ( $\mu \mathrm{g} / \mathrm{g} D W): 950$ & [113] \\
\hline Centaurium maritimum & RITA & $15 \mathrm{~min} / 45 \mathrm{~min}$ & $\begin{array}{c}\text { Total secoiridoid glycosides: } 8 \text { times } \\
\text { higher vs. liquid culture }\end{array}$ & [116] \\
\hline Centella asiatica & PlantForm & $5 \mathrm{~min} / 90 \mathrm{~min}$ & $\begin{array}{l}\text { Asiaticoside (mg/g DW): } 7.91 \text { (4.45 in } \\
\text { agitated flasks) } \\
\text { Madecassosid (mg/g DW): } 3.81 \text { (2.40 in } \\
\text { agitated flasks) }\end{array}$ & {$[120]$} \\
\hline $\begin{array}{l}\text { Chlorophytum } \\
\text { borivilianum }\end{array}$ & RITA & $15 \mathrm{~min} / 1 \mathrm{~h}$ & $\begin{array}{l}\text { Total saponin (mg diosgenin equiv./g } \\
\text { DW): } 21 \text { (16 in mother plants) }\end{array}$ & {$[121]$} \\
\hline Cymbopogon citratus & Twin Vessels & $5 \mathrm{~min} / 4 \mathrm{~h}$ & $\begin{array}{l}\alpha \text {-citral (mg/g DW): } 0.35(0.27) \\
\beta \text {-citral (mg/g DW): } 0.54(0.46)\end{array}$ & [109] \\
\hline Digitalis lanata & Two Vessels & $2 \mathrm{~min} / 4 \mathrm{~h}$ & Lanatoside C ( $\mu \mathrm{g} / \mathrm{g} \mathrm{DW}): 316$ & [122] \\
\hline Digitalis purpurea & Two Vessels & $2 \mathrm{~min} / 4 \mathrm{~h}$ & $\begin{array}{c}\text { Digitoxin }(\mu \mathrm{g}): 167.6 \\
\text { Digoxin }(\mu \mathrm{g}): 119.9\end{array}$ & [123] \\
\hline Dracocephalum forrestii & RITA & $10 \mathrm{~min} / 80 \mathrm{~min}$ & $\begin{array}{l}\text { Chlorogenic acid (mg/g DW): } 0.99(0.88 \\
\text { in NSB) } \\
\text { Acacetin rhamnosyl-trihexoside (mg/g } \\
\text { DW): } 1.01 \text { (0.91 in NSB) } \\
\text { Rosmarinic acid (mg/g DW): } 11.91 \\
\text { (18.35 in NSB) } \\
\text { Acacetin acetylrhamnosyl-trihexoside } \\
\text { (mg/g DW): } 2.45 \text { (2.25 in NSB) } \\
\text { Apigenin p-coumaroylrhamnoside II } \\
\text { (mg/g DW): } 2.28 \text { (1.76 in NSB) }\end{array}$ & {$[124]$} \\
\hline Drosera communis & Twin Bottles & $5 \mathrm{~min} / 4 \mathrm{~h}$ & $\begin{array}{l}\text { Plumbagin content }(\mu \mathrm{g} / \mathrm{g} D W): 2.44 \\
(4.22)\end{array}$ & [69] \\
\hline \multirow[b]{2}{*}{ Fabiana imbricata } & Twin Vessels & $5 \mathrm{~min} / 4 \mathrm{~h}$ & Oleanolic acid (mg/g DW): 0.01 (0.01) & [109] \\
\hline & Bottles & $10 \mathrm{~min} / 4 \mathrm{~h}$ & $\begin{array}{l}\text { Oleanolic acid (\% DW): up to } 0.14 \% \\
\text { (3.47 in wild plant) } \\
\text { Rutin (\% DW): } 0.20 \text { (3.35 in wild plant) }\end{array}$ & {$[43]$} \\
\hline Gynura procumbens & BIT & $15 \mathrm{~min} / 12 \mathrm{~h}$ & Flavonoids content mg (CE/g DW): 32.0 & [125] \\
\hline
\end{tabular}


Table 2. Cont.

\begin{tabular}{|c|c|c|c|c|}
\hline Species & Bioreactor * & $\begin{array}{l}\text { Immersion Frequency } \\
\text { (Immersion/Dry) }\end{array}$ & $\begin{array}{c}\text { Bioactive Compound in TIS } \\
\text { (vs. Semi Solid Culture System) ** }\end{array}$ & Reference \\
\hline $\begin{array}{l}\text { Harpagophytum } \\
\text { procumbens }\end{array}$ & $\begin{array}{l}\text { Two Erlenmeyer } \\
\text { Flasks }\end{array}$ & $60 \mathrm{~min} / 24 \mathrm{~h}$ & $\begin{array}{c}\text { Harpagoside (mg/gDW): } \\
\text { Leaves: } 6.0 \text { (3.5 in glasshouse grown } \\
\text { plants) } \\
\text { Stem: } 3.8 \text { ( } 5 \text { in glasshouse grown plants) } \\
\text { Root: } 8 \text { ( } 2 \text { in glasshouse grown plants) }\end{array}$ & [114] \\
\hline Hypericum perforatum & Twin Vessels & $5 \mathrm{~min} / 4 \mathrm{~h}$ & Hypericin (mg/g DW): 0.18 (0.15) & [109] \\
\hline Lavandula officinalis & Twin Vessels & $5 \mathrm{~min} / 4 \mathrm{~h}$ & Rosmarinic acid (mg/g DW): 5.7 (55.3) & [109] \\
\hline \multirow[b]{2}{*}{ Leucojum aestivum } & Bioreactor Vessels & $5 \mathrm{~min} / 2 \mathrm{~h}$ & Galanthamine (mg/l): 4.64 & [126] \\
\hline & RITA & $15 \mathrm{~min} / 8 \mathrm{~h}$ & $\begin{array}{c}\text { Galanthamine ( } \mu \mathrm{g} / \mathrm{RITA}): 265 \\
\text { Lycorine ( } \mu \mathrm{g} / \mathrm{RITA}): 1.699 \\
\text { Norgalanthamine ( } \mu \mathrm{g} / \mathrm{RITA}): 225\end{array}$ & [127] \\
\hline Lycium barbarum & PlantForm & $6 \mathrm{~min} / 24 \mathrm{~h}$ & $\begin{array}{c}\text { Total phenol (mg GAE/g DW): } 23.6 \\
\text { (19.4) } \\
\text { Total flavonoid (mg RE/g DW): } 1.9 \\
(18.5)\end{array}$ & [107] \\
\hline Nasturtium officinale & RITA & not reported & $\begin{array}{l}\text { Total polyphenols (mmol TE/100 g } \\
\text { DW): } 3.74 \text { ( } 2.70 \text { in mother plants) } \\
\text { Total flavonoids (mmol RE/100 g DW): } \\
1.64 \text { (1.89 in mother plants) } \\
\text { Total glucosionolates (mg/100 g DW): } \\
261.97 \text { (799.47 in mother plants) }\end{array}$ & [128] \\
\hline \multirow{2}{*}{ Panax ginseng } & RITA & $5 \mathrm{~min} / 1 \mathrm{~h}$ & Saponin (mg/g DW): 15.94 & [129] \\
\hline & RITA & $5 \mathrm{~min} / 1 \mathrm{~h}$ & Saponin (mg/g DW): 28.51 & [130] \\
\hline Pancratium maritimum & RITA & $15 \mathrm{~min} / 12 \mathrm{~h}$ & $\begin{array}{c}\text { Alkaloid }(\mu \mathrm{g} / \mathrm{g} D W): 3.469 \\
\text { Haemanthamine }(\mu \mathrm{g} / \mathrm{g}): 900.1 \\
\text { Lycorine }(\mu \mathrm{g} / \mathrm{g}): 799.9\end{array}$ & [131] \\
\hline $\begin{array}{l}\text { Rhododendron } \\
\text { tomentosum }\end{array}$ & RITA & $5 \mathrm{~min} / 85 \mathrm{~min}$ & $\begin{array}{l}\text { p-cymene (\%): } 6.9(0.9) \\
\text { Alloaromadendrene (\%): } 5.5(8.1) \\
\text { Shyobunone (\%): } 8.2(15.8) \\
\text { Ledene oxide (II) }(\%): 13.0(14.7)\end{array}$ & [115] \\
\hline Rosa canina & RITA & $\begin{array}{l}15 \mathrm{~min} / 12 \mathrm{~h} \\
15 \mathrm{~min} / 6 \mathrm{~h} \\
15 \mathrm{~min} / 8 \mathrm{~h}\end{array}$ & $\begin{array}{c}\text { Total phenolics (mg/g FW): } 15.8(11.4) \\
\text { Soluble sugars (mg/g FW): } 9.2(8.0) \\
\text { Carotenoids (mg/g FW): } 0.66(0.99)\end{array}$ & [132] \\
\hline Rosa rubiginosa & RITA & $15 \mathrm{~min} / 8 \mathrm{~h}$ & $\begin{array}{l}\text { Total phenolics (mg/g FW): } 8.03 \text { (9.57) } \\
\text { Carotenoids (mg/g FW): } 0.10(0.17) \\
\text { Soluble sugars (mg/g FW): } 9.41 \text { (7.99) }\end{array}$ & [108] \\
\hline Rosa rugosa & ВТВB & not reported & $\begin{array}{l}\text { Total phenolics (mg/g DW): } 10 \text { (22) } \\
\text { Total flavonoids (mg/g DW): } 3 \text { (3.5) }\end{array}$ & [133] \\
\hline Rosa tomentosa & RITA & $15 \mathrm{~min} / 8 \mathrm{~h}$ & $\begin{array}{c}\text { Total phenolics (mg/g FW): } 9.91 \text { (9.66) } \\
\text { Carotenoids (mg/g FW): } 0.11(0.09) \\
\text { Soluble sugars (mg/g FW): } 7.34 \text { (9.39) }\end{array}$ & [108] \\
\hline
\end{tabular}


Table 2. Cont.

\begin{tabular}{|c|c|c|c|c|}
\hline Species & Bioreactor * & $\begin{array}{l}\text { Immersion Frequency } \\
\text { (Immersion/Dry) }\end{array}$ & $\begin{array}{c}\text { Bioactive Compound in TIS } \\
\text { (vs. Semi Solid Culture System) ** }\end{array}$ & Reference \\
\hline Salvia viridis & PlantForm & $10 \mathrm{~min} / 80 \mathrm{~min}$ & $\begin{array}{l}\text { Total phenolic acid (mg/g DW): } 18.3 \\
\text { Total phenylethanoid (mg/g DW): } 11.4 \\
\text { Total phenol (mg/g DW): } 29.7\end{array}$ & [134] \\
\hline \multirow[t]{2}{*}{ Schisandra chinensis } & PlantForm & $5 \mathrm{~min} / 90 \mathrm{~min}$ & $\begin{array}{c}\text { Lignans (mg/100 g DW): } 546.98 \text { (185.77 } \\
\text { in agitated cultures) } \\
\text { Schisandrin (mg/100 g DW): } 118.59 \\
\text { Deoxyschisandrin (mg/100 g DW): } \\
77.66 \\
\text { Gomisin A (mg/100 g DW): } 67.86\end{array}$ & [135] \\
\hline & PlantForm, RITA & $5 \mathrm{~min} / 90 \mathrm{~min}$ & $\begin{array}{l}\text { Total phenolic acids (mg / } 100 \mathrm{~g} \mathrm{DW}) \text { : } \\
34.56 \text { in PlantForm ( } 46.68 \text { in continuous } \\
\text { immersion) } \\
\text { Total flavonoids ( } \mathrm{mg} / 100 \mathrm{~g} \mathrm{DW}): 21.27 \\
\text { in RITA ( } 29.02 \text { in continuous immersion) }\end{array}$ & [136] \\
\hline Scutellaria baicalensis & RITA & $5 \mathrm{~min} / 3 \mathrm{~h}$ & $\begin{array}{c}\text { Baicalein ( } \mu \mathrm{g} / \mathrm{mg} \text { DW): } 2.2(1.1) \\
\text { Baicalin }(\mu \mathrm{g} / \mathrm{mg} \text { DW): } 3.0(1.0) \\
\text { Wogonin }(\mu \mathrm{g} / \mathrm{mg} \text { DW): } 0.10(0.25)\end{array}$ & [110] \\
\hline Stevia rebaudiana & BIT & $3 \mathrm{~min} / 6 \mathrm{~h}$ & $\begin{array}{l}\text { Total steviol glycosides/container }(\mathrm{g}) \text { : } \\
0.1698(0.0239)\end{array}$ & [111] \\
\hline Thapsia garganica & RITA & $3 \mathrm{~min} / 6 \mathrm{~h}$ & $\begin{array}{l}\text { Thapsigargin (mg/g DW): } 2.15 \\
\text { Nortrilobolide (mg/g DW): } 17.42\end{array}$ & [137] \\
\hline $\begin{array}{l}\text { Vaccinium vitis-idaea } \\
\text { ssp. minus }\end{array}$ & RITA & not reported & $\begin{array}{c}\text { Carotenoids }(\mu \mathrm{g} / \mathrm{mL}): 0.40(0.30 \text { in } \\
\text { stationary bioreactor) }\end{array}$ & [112] \\
\hline Zeltnera beyrichii & RITA & $15 \mathrm{~min} / 6 \mathrm{~h}$ & $\begin{array}{c}\text { Secoiridoid glycoside (mmol per } 100 \mathrm{~g} \\
\text { DW): } 7.5 \text { (30) }\end{array}$ & [138] \\
\hline
\end{tabular}

${ }^{*}$ Different names of Twin Flasks (bottles, two vessels, twin bottles, twin vessels) refer essentially to analogous TIS systems. ${ }^{* *}$ Values between parentheses refer to the semi-solid culture, if not differently specified. DW: dry weight, DVS: Dual-Vessel System, NSB: Nutrient Sprinkle Bioreactor; FW: fresh weight, BTBB: Balloon-Type Air-Lift Bubble Bioreactor.

\subsection{Type of TIS Bioreactors}

Over last 20 years, the RITA ${ }^{\circledR}$ system has been the most used bioreactor $(39.8 \%$ of the reported papers) to produce biomass (31.3\%) and metabolites (53\%) (Figure 3); it has also been the first bioreactor to be designed and sold on the market by a commercial company (Vitropic, France, https:/ / www.cirad.fr accessed on 20 November 2021). Different plant species have responded successfully to the RITA system, such as vanilla [101], pistachio [32], and cork oak [139]. Following the Twin-Flask system is one of the earliest developed TIS [140], and it was used in $24 \%$ of the papers. This model has a simple operation and often has been, or is still, custom-made in the laboratory and is called by various names (e.g., BIT $^{\circledR}$, TIB, two vessels, two bottles, etc.).

The RITA and the Twin-Flask bioreactors are widely used for metabolite production (53\% and 24\%, respectively; Figure 3). BIT or TIB (Temporary Immersion Bioreactor; [140]), a registered trademark bioreactor working on the principle of Twin-Flask containers, was present in $12 \%$ of applications for biomass and $5 \%$ for bioactive compounds production. PlantForm ${ }^{\mathrm{TM}}$ bioreactor (http:/ / www.plantform.se/ (accessed on 20 November 2021) was proposed more recently and, for this reason, only 13 papers reported its application. Plantima, Ebb, and Flow devices [29] are used in medicinal plants only for mass propagation. Other types of bioreactors are applied in biomass (7.5\%) and metabolites yield $(7 \%)$, among which is the SETIS ${ }^{\mathrm{TM}}$ (https:/ / setis-systems.be (accessed on 20 November 2021), a bioreactor of the last generation that has proven to be very promising in various species [141-143]. 


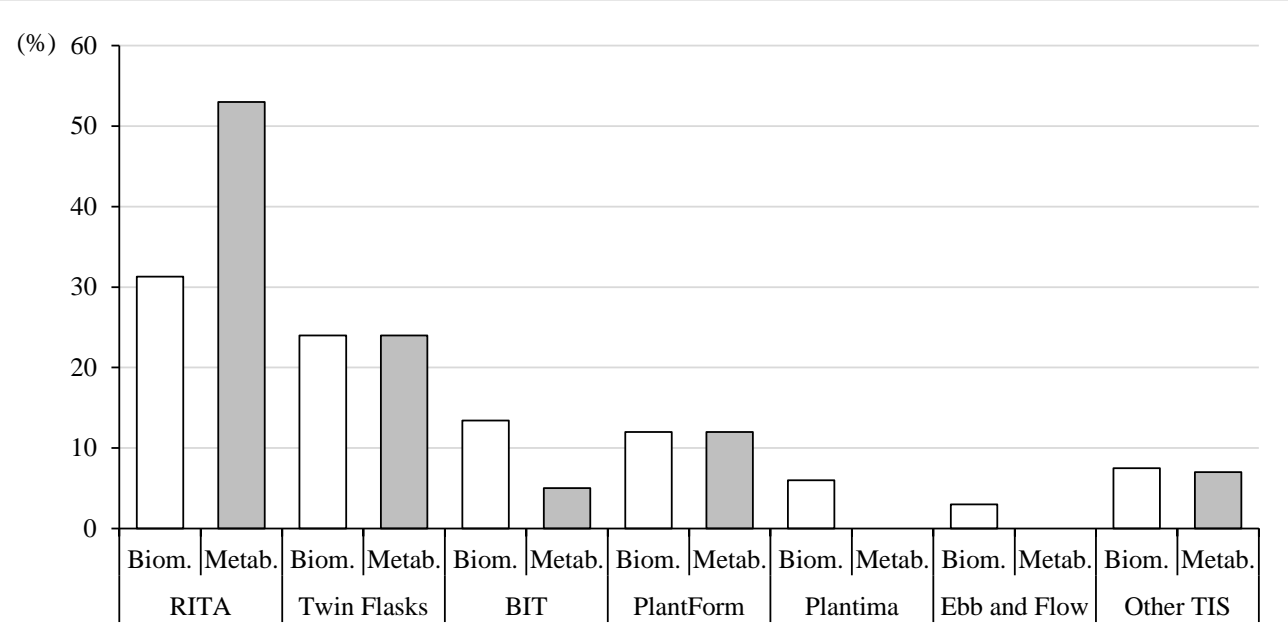

Figure 3. TIS bioreactors application percentage in the reported papers for biomass (61 papers) and bioactive compounds production (36 papers).

The specific design of a given TIS has a direct effect on the in vitro development of plants [29]. This is mainly because each system provides different physical culture conditions which, in turn, have a direct impact on the in vitro environment, light availability, space, water, and nutrients [29,135]. RITA, Twin Flasks, and PlantForm differ mainly in the volume of the containers and type of ventilation, being passive in the first two and forced in the last. Moreover, TIS design and materials influence the transmission of light to plant [29] and light irradiance directly affects the synthesis of photosynthetic pigments and the photosynthetic rate of plants cultivated in vitro [144]. Although the different effectiveness is evident in the literature, only a few papers investigated the effect of various types of TIS on the propagation and the production of metabolites in the same species.

\subsubsection{Types of TIS Bioreactors and Biomass Production}

Different types of TIS were compared in Anthurium andreanum during the in vitro propagation. The largest number of shoots per explant was 50.83 and 43.16 with TIB and Ebb and Flow, respectively, compared to 30.66 with RITA; moreover, in TIB the shoots showed a greater photosynthetic efficiency [46] (Table 1). Additionally, other studies on the micropropagation of anthurium reported 31.50 shoots per explant with the Ebb and Flow bioreactor [47] and a multiplication rate of 5.17 with the RITA system [45].

The liquid culture in PlantForm or RITA bioreactors was found to be efficient for Stevia rebaudiana propagation, with the number of shoots per explant equal to 14 , as well as for its rooting phase [94]. The authors noted that, although the PlantForm has a larger space to allow for material enlargement rather than RITA, it is necessary to carefully set the flooding conditions with the PlantForm system to obtain good quality plants suitable for the acclimatization phase in greenhouse; flooding every $8 \mathrm{~h}$ guaranteed a better behavior and quality without hyperhydricity. A smaller number of explant per shoots (11.8 and 8.47) was obtained by Ramírez-Mosqueda and Iglesias-Andreu [95] and Bayraktar [97], respectively, always using the RITA for the micropropagation of stevia. Furthermore, three TIS bioreactors, SETIS, RITA and BIT, were compared for the propagation of two stevia cultivars and their performance in the field was evaluated (Rosales et al., 2018). Each system produced vigorous plants with low levels of hyperhydricity, great average numbers of leaves and shoots, and a higher rate of multiplication than those explants cultured in semi-solid medium. In particular, the BIT container showed the best results in terms of plant elongation and shoots per explant. The efficacy of BIT documented in some species, including vanilla [95], is due to the easy availability of components in the laboratories and 
easy assembling [29,145]. Ramirez-Mosqueda and Iglesias-Andreu [95] compared three different bioreactors during the multiplication and the rooting of Vanilla planifolia: BIT, Gravity Immersion Bioreactors (BIG), and RITA. A higher number of shoots per explant (18.06) was obtained in the multiplication phase in BIT systems, followed by RITA (12.77) and BIG (6.83). In addition, the fresh and dry weights of shoots and the number of longer roots were higher in the BIT compared with the other systems. The efficiency of the RITA system in vanilla propagation was also evaluated by Ramos-Castellà et al. [101] and Spinoso-Castillo et al. [102], which obtained 14.27 as the multiplication rate and 14.89 shoots per explant, optimizing two types of immersion.

\subsubsection{Type of TIS Bioreactors and Bioactive Compounds Content}

The selection of bioreactor type and optimization of process parameters are decisive for maximizing secondary metabolite production $[19,21,110,146]$. Many kinds of bioactive compounds have been explored and produced in different types of bioreactors (Table 2). Total phenolics, total flavonoids, and total carotenoids from different medicinal plants were the main groups of metabolites studied in TIS. The role of plant-derived phenolic substances in various areas such as medicine, cosmetology, and food industry is precious, and compounds like flavonoids and phenolic acids with scientific evidence are used for many important biological activities as antioxidants [147,148], anti-inflammatories [149], or anticancer properties [150]. The RITA system is the bioreactor most used in the production of phenols and flavonoids, such as in Castilleja tenuiflora, Nasturtium officinale, Schisandra chinensis, and Zeltnera beyrichii. In particular, a higher total polyphenol content (3.74 mmol trolox equivalent-TE/100 g DW) was obtained from Nasturtium officinale microshoots cultured in RITA system over 10 days, which was 1.4-fold higher in comparison to the herb extracts from the mother plants, while the total flavonoid content was $1.64 \mathrm{mmol} \mathrm{RE} / 100 \mathrm{~g}$ DW after 10 days of growth in RITA bioreactor respect to $1.89 \mathrm{mmol}$ $\mathrm{RE} / 100 \mathrm{~g}$ DW in the herb extract from mother plants [128]. Some papers report the production of phenolics from Rosa spp. High contents were obtained for R. canina (15.8 mg/g FW), R. rubiginosa ( $8.03 \mathrm{mg} / \mathrm{g} \mathrm{FW})$, and R. tomentosa $(9.91 \mathrm{mg} / \mathrm{g} \mathrm{FW})$ by the application of the RITA system [108,132]. Using a Balloon-Type Air-Lift Bubble Bioreactor (BTBB) adapted for temporary immersion culture in $R$. rugosa led to less total phenolics and total flavonoids compared to a continuous immersion bioreactor [133].

The influence of bioreactor type on the accumulation of phenolic acids and flavonoids in microshoot cultures of Schisandra chinensis was proven and optimized when comparing five different bioreactors: three with continuous immersion and two with temporary immersion [136]. The tested TIS bioreactors, RITA and PlantForm, were always better than the continuous immersion system in relation to biomass productivity, while the continuous immersion systems showed the best results in terms of phenolic acids and flavonoids contents. Taking into account only TIS systems, small differences were recorded in the accumulation of two groups of phenolic compounds: indeed, the production of phenolic acids was $34.56 \mathrm{mg} / 100 \mathrm{~g}$ DW in PlantForm and $32.65 \mathrm{mg} / 100 \mathrm{~g}$ DW in RITA, and the one with flavonoids was $21.27 \mathrm{mg} / 100 \mathrm{~g}$ DW in RITA and $20.48 \mathrm{mg} / 100 \mathrm{~g}$ DW in PlantForm [136]. In the same species, PlantForm and RITA systems were compared for the production of lignans [135]. Best results were obtained by the PlantForm bioreactor (546.98 mg/100 g DW), in terms of the main lignan constituents: schisandrin, deoxyschisandrin, and gomisin A.

Total phenols and flavonoids were recorded in vitro culture of Lycium barbarum cultivated in PlantForm [107]. Here, the TIS culture resulted in an increase of the total phenolic content and a lower value of the total flavonoid content, with respect to the control with a semi-solid culture system. Superior results were obtained in Salvia viridis using PlantForm as TIS bioreactor in comparison to in vivo plants. Indeed, after three culture weeks, the total phenolic acids level was almost 10 times higher than in four-month-old plants growing in the soil [134]. Zeltnera beyrichii plants grown in a RITA bioreactor contained moderate levels of total phenolics [138]. 
The PlantForm bioreactor turned out to be the best system in terms of phenolic acids, flavonoids, and centellosides productivity in Centella asiatica [120] compared to the RITA bioreactor and agitated flasks in the continuous system. The production of total phenolic compounds, mainly chlorogenic acid and rosmarinic acid, was recorded in Dracocephalum forrestii shoots, a tibetan medicinal plant, cultured in RITA bioreactor. However, the conditions were different for flavonoid glycosides, where PlantForm was more effective for the production of the apigenin p-coumaroyl-rhamnoside II and acacetin acetylrhamnosyl-trihexoside [124]. Rosmarinic acid, a bioactive compound with the most prominent antibacterial, anti-inflammatory, and antiviral activities [151], was also produced from Lavandula officinalis using the Twin-Flask system, although the amount was higher in semi-solid culture [109].

Another important group of bioactive substances, the carotenoids, were produced in TIS. Carotenoids, as potent antioxidants, are recognized as playing an important role in the prevention of human diseases and the maintenance of good health (Rao and Rao, 2007). In Rosa canina [132], R. rubiginosa, and R. tomentosa [108], the carotenoid content was $0.66,0.10$, and $0.11 \mathrm{mg} / \mathrm{g}$ FW, respectively, when this species was propagated in the RITA system, while in the same type of bioreactor Vaccinium vitis-idea produced $0.40 \mu \mathrm{g} / \mathrm{mL}$ of carotenoids [112].

In the RITA bioreactor, an eight-times higher total secoiridoid glycosides production rate was achieved in Centaurium maritimum, a plant which contains a considerable amount of bioactive compounds [116]; in addition, a high saponin content was found in adventitious roots Panax ginseng cultivated in RITA [130]. It is also interesting to note that the shoot culture in two vessels of Digitalis purpurea promoted both a high biomass production and a high of cardiotonic glycoside [123]. Recently, in maqui (Aristotelia chilensis) the contents of metabolites in TIBs did not differ from those of wild plants [49]. The authors suggest some observations for the scaling up to SETIS bioreactors as a system to improve the production efficiency of phenylpropanoids.

\subsection{Immersion Frequency}

In every system of TIS liquid culture, the selected cycle of immersion is the most critical parameter for the system efficiency. Tables 1 and 2 show a considerable variation of immersion times, ranging from hours to a few seconds due to the large variety of species, micropropagation processes, and TIS used.

\subsubsection{Immersion Frequency and Biomass Production}

An immersion frequency of $30 \mathrm{~s}$ every $30 \mathrm{~min}$ or every $3 \mathrm{~h}$ produced the highest number of shoots per explant in Jeffersonia dubia [78] and in Eucalyptus grandis $\times$ E. urophylla ([70] (Table 1). The effect of immersion interval (15 min immersion every $4 \mathrm{~h}$ ) was more critical in Aquilaria malaccensis shoot cultivation when an increase in the number of shoot regeneration (5.12) and biomass (3.12 g) were obtained compared to $5 \mathrm{~min} / 4 \mathrm{~h}$ [48].

In order to increase the regeneration rate of Charybdis numidica, the immersion frequency was doubled from $5 \mathrm{~min} / 24 \mathrm{~h}$ to $5 \mathrm{~min} / 12 \mathrm{~h}$. However, it turned out that the shoots became very sensitive to the prolonged contact with the nutrient medium, resulting in completely hyperhydrated shoots [56]. The effect of TIS at two, four, and six immersions per day on the biomass production of Cymbopogon citratus was studied. The maximum values of FW (66.2 g) were obtained in the treatments of four and six immersions per day, whereas the values of DW $(6.4 \mathrm{~g})$ were greater in the frequency of four immersions per day [59]. Significant and distinctive differences were recorded by Ahmadian et al. [63] in vitro Dianthus caryophyllus propagation using TIS. Although increasing the immersion times induced the greatest number of new shoots, the highest rate of hyperhydricity was observed. Since hyperhydricity is a remarkable sign of inefficiency of TIB, the most desirable treatment was four immersions of $2 \mathrm{~min} /$ day with 14.33 new shoots. In a later study on the same species, incidence of hyperhydricity was greater $(62 \%)$ in plantlets cultured with the 2-h dry phase and reduced to $16 \%$ when the dry phase increased to $8 \mathrm{~h}$ with 
$60 \mathrm{~s}$ [64]. However, the best results suggest that carnation in TIS with $90 \mathrm{~s}$ immersion every $8 \mathrm{~h}$ had superior growth traits, normal shapes, a higher number of stomata, and total absence of hyperhydricity.

The influence of immersion frequency and duration on in vitro propagation of medicinal and aromatic plants was investigated by Wawrosch [72]. An immersion setting of $5 \mathrm{~min} / 4 \mathrm{~h}$ was proven to enhance the multiplication rate of Glycyrrhiza glabra (9.47), while $5 \mathrm{~min} / 8 \mathrm{~h}$ improved the multiplication of Saponaria officinalis (4.36), Tussilago farfara (5.65), and Picrorhiza kurroa (8.20). For Helichrysum italicum, the best multiplication rate (16.4) was obtained with only one immersion per day (i.e., $5 \mathrm{~min} / 24 \mathrm{~h}$ ), considering that a notable decline was found during the immersion of 1 or 5 min every $8 \mathrm{~h}$.

A longer immersion time of $3 \mathrm{~h}$ was efficient to proliferate Pistacia lentiscus, a species with difficult propagation, either by seed or by cuttings [88], whereas shortest times of only $10 \mathrm{~s}$ succeed to micropropagate Stevia rebaudiana through a TIS bioreactor; in particular, maximum values of number of shoots per explant (8.47) were obtained with immersion for $10 \mathrm{~s} / 1 \mathrm{~h}[97]$.

\subsubsection{Immersion Frequency and Bioactive Compounds Content}

As reported above, the significant effect of the immersion cycle on biomass accumulation was evidenced in medicinal plants, and thus it is important to highlight its impact on the large-scale production of bioactive compounds as well (Table 2).

Castilleja tenuiflora shoots from an immersion cycle of 30 min every $24 \mathrm{~h}$ showed the highest total phenolics ( $30.58 \mathrm{mg} \mathrm{GAE} / \mathrm{g}$ DW) and total flavonoid content (45.83 $\mu \mathrm{g}$ $\mathrm{CE} / \mathrm{g} \mathrm{DW}$ ) [118], while a lower immersion frequency of 15 min every $12 \mathrm{~h}$ increased only the flavonoid (32.00 mg catechin equivalent-CE/g DW) in shoot culture of Gynura procumbens [125]. In Rosa canina plantlets, two immersions per day (15 $\mathrm{min} / 12 \mathrm{~h})$ led to larger content of phenolic compounds $(15.8 \mathrm{mg} / \mathrm{g} \mathrm{FW})$, whereas more immersions (15 min/6 h) produced a higher accumulation of soluble sugars (9.2 mg/g FW; [132]). On the other hand, both betalains (betacyanins and betaxanthins) in hairy root culture of Beta vulgaris [117] and saponin in microtubers from Chlorophytum borivilianum [121] increased at 15-min flooding every $1 \mathrm{~h}$ during the cultivation in RITA.

As cardiotonic glycosides (digitoxin, digoxin, and lanatoside C) are secondary metabolites of high value for the pharmaceutical industry, it was interesting to enhance their net production in Digitalis purpurea shoots cultured in TIS at six immersions per day ( $2 \mathrm{~min} / 4 \mathrm{~h}$ ) [123]. Valuable Amaryllidaceae-type alkaloids, such as galanthamine, its precursor norgalanthamine, and lycorine, were gained from Leucojum aestivum with $15 \mathrm{~min} / 8 \mathrm{~h}$ as the immersion cycle [127]. In Pancratium maritimum shoots, the biosynthesis of alkaloid was affected by the immersion frequency. An immersion frequency with $15 \mathrm{~min} / 12 \mathrm{~h}$ increased the content of total intracellular alkaloid by $58 \%$ and $54 \%$ as compared to $15 \mathrm{~min} / 6 \mathrm{~h}$ and $15 \mathrm{~min} / 24 \mathrm{~h}$, respectively [131]. The immersion of $10 \mathrm{~min} / 80 \mathrm{~min}$ was effective to optimize the accumulation of total phenolic acid, total phenylethanoid, and total phenol contents in shoots of Salvia viridis [134].

\subsection{Influence of TIS on Medium Composition}

The content of the nutrient solution used in TIS cultures plays a key role in plant growth. It should be also noted that, in some cases, the liquid culture in TIS can contribute to the use of a lower number of mineral salts and PGRs in comparison to the conventional culture in semi-solid medium. Indeed, the use of liquid media, in addition to reducing the production costs by eliminating the gelling agent [152], contributes to a more efficient use of the culture medium, as the explants are in direct contact with the liquid medium during the immersion period and can absorb the nutrients more effectively $[26,30,153]$.

\subsubsection{Medium Composition and Biomass Production}

In Myrtus communis, the propagation in PlantForm (Figure 4) at an immersion cycle of $8 \mathrm{~min} / 16 \mathrm{~h}$ allowed the reduction of the macro- and micronutrients concentration in the 
liquid medium by half without compromising their growth rates, and therefore greatly reduced propagation costs [82].
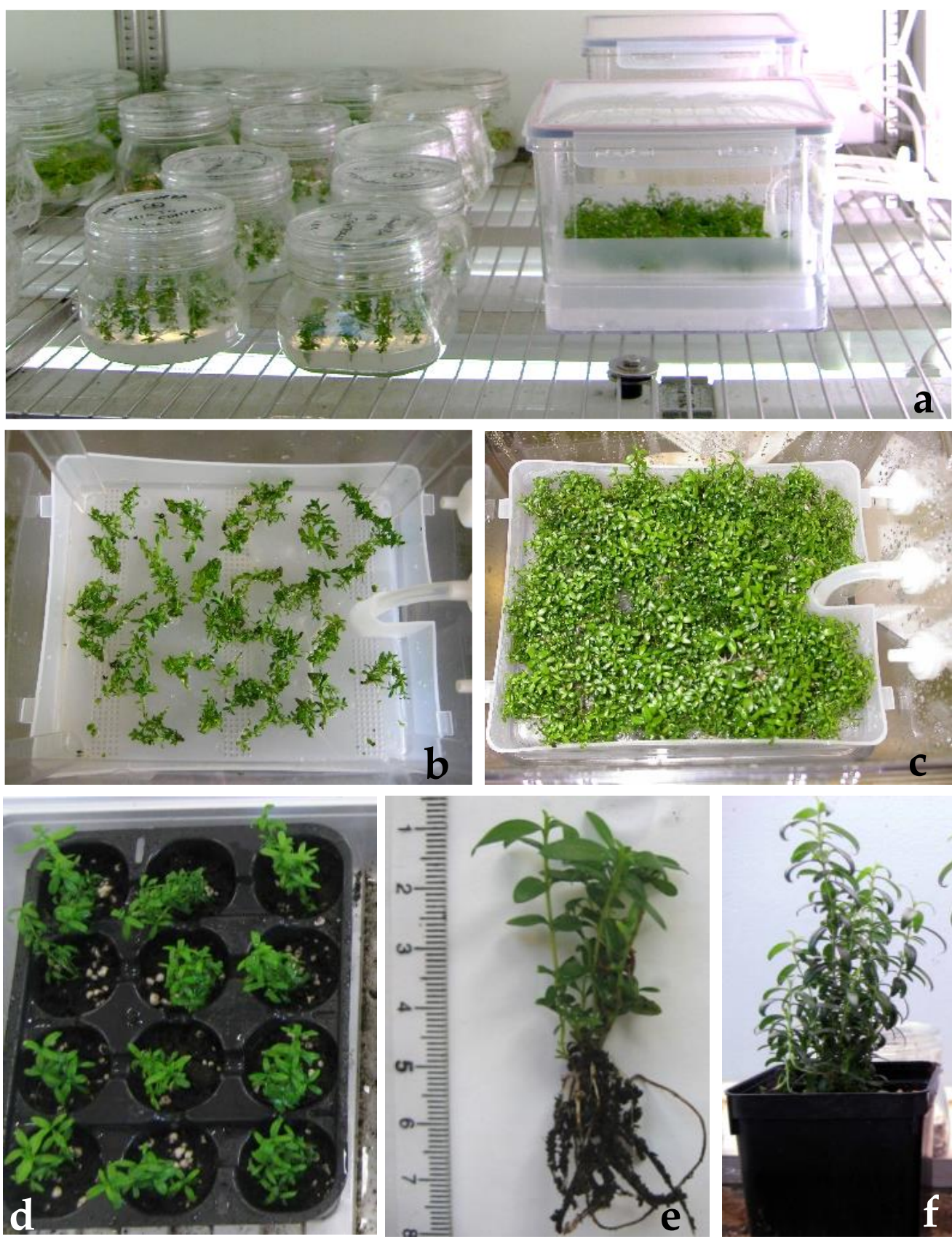

Figure 4. Micropropagation of Myrtus communis in semi-solid medium and in PlantForm bioreactor (a); shoots at the beginning of culture in PlantForm (b); shoots after 8 weeks of culture in PlantForm (c); plants after 2 weeks (d), 4 weeks (e), and 4 months (f) of ex vitro acclimatization (Photo by De Carlo A).

The effect of the PGRs present in the liquid culture medium is more efficient in the TIS system, as demonstrated by Benelli and De Carlo [84], for the micropropagation of olive trees using PlantForm with a cycle of $8 \mathrm{~min} / 16 \mathrm{~h}$. Despite the stringent hormonal needs of the in vitro olive tree, it was possible to reduce the concentration of zeatin by half; there were no significant differences in shoot length when 5 or $10 \mu \mathrm{M}$ zeatin was applied (3.04 and $3.13 \mathrm{~cm}$, respectively). The need for this expensive hormone for the propagation of the olive tree is well known to obtain an efficient multiplication rate in this species. 
Some authors have monitored the effect of different sucrose concentrations in the culture substrate on biomass production. In particular, Curcuma zedoaria, Zingiber zerumbet, Gynura procumbens, and Bletilla striata have showed that a higher concentration of sugar improves the performance of explants $[52,62,73]$, whereas a significant increase in shoots number (13.05) of Bambusa vulgaris was noted in TIS with a sucrose-free medium [51].

The growth of Aristotelia chilensis in a two-vessels bioreactor under optimized photomixotrophic conditions using reduced concentration of sucrose $(1 \%$ and $2 \%)$ and airsupplemented with $\mathrm{CO}_{2}(0.4 \mathrm{MPa})$ did not differ significantly in biomass production (FW per cluster of plants) compared to the control treatment with sucrose $3 \%$ and standard air [49].

Rosales et al. [96] tested the efficacy of five substrates for the cultivation of Stevia rebaudiana in TIS (BIT bioreactor): different concentrations of sucrose (30 or $40 \mathrm{~g} / \mathrm{L}$ ), presence or absence of kinetin $(1 \mathrm{mg} / \mathrm{L})$, and a microbiological suppressant $(1 \mathrm{~mL} / \mathrm{L}$ of methylisothiazolone and methylchloroisothiazolinone) were added to the basal medium. In a culture medium containing $30 \mathrm{~g} / \mathrm{L}$ sucrose and microbiological suppressant, the best results were observed during ex vitro acclimatization, reporting survival in $92 \%$ of plants. With Anthurium andraeanum cultured in RITA at an immersion cycle of $3 \mathrm{~min} / 3 \mathrm{~h}$, the presence of 6-benzylaminopurine (BA) alone increased the multiplication rate better than the combination of BA with the other hormones (indole-3-acetic acid, gibberellic acid) [45].

\subsubsection{Medium Composition and Bioactive Compounds Content}

The content of total phenolic compounds, as well as phenylethanoid glycosides verbascoside and isoverbascoside, were increased in Castilleja tenuiflora shoots exposed to modified B5 culture medium [154] containing less nitrogen amounts using the RITA system at $5 \mathrm{~min} / 24 \mathrm{~h} \mathrm{[119].}$

The combination of elicitor (Chitoplant ${ }^{\circledR}$ ) and TIS (two vessels bioreactor), as a reliable alternative for the genetic modification, increased the cardenolides production 2.2-fold in Digitalis lanata shoots [122], significantly improved galanthamine content in the leaves and bulblets of Leucojum aestivum [126], and stimulated the production of thapsigargin and nortrilobolide in vitro Thapsia garganica shoots [137]. Moreover, the elicitation induced the production and accumulation of phenylpropanoid metabolites in both fresh biomass and culture medium of Aristotelia chilensis [49].

Since the concentration and the type of PGRs are often considered a crucial factor for the accumulation of secondary metabolites, Langhansova et al. [129] found that medium containing benzo[b]selenienyl acetic acid (BSAA) and kinetin was the most suitable for a large-scale production of saponin in Panax ginseng cultured in TIS (RITA bioreactor).

\section{Conclusions and Perspectives}

The production of secondary metabolites of industrial interest (for health, cosmetics, and food use) is frequently based on the exploitation of natural plant resources through the collection of endemic species not subject to specialized cultivation, thus compromising their genetic resources. When these substances are found in cultivated species, the extraction rates are often so limited that are not economically advantageous. For this reason, it is of strategic importance to search for alternative ways of obtaining these substances in large quantities. The modern biotechnology offered today provides important tools for the production of biomass and bioactive compounds, consistently limiting the exploitation of natural resources. The micropropagation in bioreactors using liquid media has significant potential for commercial purposes, in particular with the application of the liquid culture in TIS, where the brief contact times of the plant material with the liquid medium allows it to limit its decay while maintaining high biomass production values. Since the first report of TIS application on medicinal plants, much research has been carried out and progress in science and technology has made a great step forward, as highlighted in this review.

The research highlights the need to continue developing and optimizing effective liquid culture protocols in TIS bioreactors in order to enhance, as much as possible, the 
production of biomass, the number of subculture cycles, and the concentration in plant tissues of bioactive compounds of health interest. Moreover, ease in the operation and handling of the devices and improvement of the automation are desirable, so as to expand the possibility to apply the system on a large scale with decrease in the production costs at a commercial level. Through a literature review, the present paper argues that TIS culture can be a strategy to enhance the supply and quality of plants used for medicinal purposes. For example, in Curcuma longa the objective was to develop and refine the in vitro multiplication system for mass propagation by TIS, thus to help restore the fragile ecosystem on Rapa Nui, given that the potential overexploitation of this medicinal plant raises doubts about its long-term survival in this area [61]. The advances in TIS culture represent a way which will enable rapid multiplication and sustainable use of medicinal plants for future generations, contributing to meeting the social, economic, and commercial demands, but with the awareness to preserve plants as essential natural resources.

Author Contributions: Conceptualization, A.D.C. and C.B.; data collection and analysis, preparation of the tables, A.D.C. and W.T.; writing-original draft preparation, A.D.C., W.T. and C.B.; writingreview and editing, W.T. and C.B.; supervision, M.L. All authors have read and agreed to the published version of the manuscript.

Funding: This research received no external funding.

Data Availability Statement: The data presented are available in all the publications cited in this review.

Conflicts of Interest: The authors declare no conflict of interest.

\section{References}

1. Chandran, H.; Meena, M.; Barupal, T.; Sharma, K. Plant tissue culture as a perpetual source for production of industrially important bioactive compounds. Biotechnol. Rep. 2020, 26, e00450. [CrossRef]

2. Allen, D.; Bilz, M.; Leaman, D.J.; Miller, R.M.; Timoshyna, A.; Window, J. European Red List of Medicinal Plants; Publications Office of the European Union: Luxembourg, Germany, 2014; ISBN 9789279474507.

3. Rout, G.R.; Samantaray, S.; Das, P. In vitro manipulation and propagation of medicinal plants. Biotechnol. Adv. 2000, 18, 91-120. [CrossRef]

4. Chaturvedi, H.C.; Jain, M.; Kidwai, N.R. Cloning of medicinal plants through tissue culture-A review. Indian J. Exp. Biol. 2007, 45, 937-948. [PubMed]

5. Gantait, S.; Mandal, N.; Nandy, S. Advances in micro propagation of selected aromatic plants: A review on vanilla and strawberry. Am. J. Biochem. Mol. Biol. 2011, 1, 1-19. [CrossRef]

6. Bajaj, Y.P.S.; Furmanowa, M.; Olszowska, O. Biotechnology of the Micropropagation of Medicinal and Aromatic Plants. In Medicinal and Aromatic Plants I. Biotechnology in Agriculture and Forestry; Bajaj, Y.P.S., Ed.; Springer: Berlin/Heidelberg, Germany, 1988; Volume 4, pp. 60-103.

7. Constabel, F. Medicinal Plant Biotechnology. Planta Med. 1989, 56, 421-425. [CrossRef] [PubMed]

8. Zhou, L.G.; Wu, J.Y. Development and application of medicinal plant tissue cultures for production of drugs and herbal medicinals in China. Nat. Prod. Rep. 2006, 23, 789-810. [CrossRef] [PubMed]

9. Yadav, K.; Singh, N.; Verma, S. Plant tissue culture: A biotechnological tool for solving the problem of propagation of multipurpose endangered medicinal plants in India. J. Agric. Technol. 2012, 8, 305-318.

10. Máthé, Á.; Hassan, F.; Kader, A.A. In Vitro Micropropagation Of Medicinal and Aromatic Plants. In Medicinal and Aromatic Plants of the World. Medicinal and Aromatic Plants of the World; Máthé, Á., Ed.; Springer: Dordrecht, The Netherlands, 2015; Volume 1, pp. 305-336.

11. Moraes, R.M.; Cerdeira, A.L.; Lourenço, M.V. Using micropropagation to develop medicinal plants into crops. Molecules 2021, 26, 1752. [CrossRef]

12. Moraes-Cerdeira, R.M.; Burandt, C.L.; Bastos, J.K.; Nanayakkara, N.P.D.; Mc Chesney, J.D. In vitro propagation of Podophyllum peltatum. Planta Med. 1998, 64, 42-45. [CrossRef]

13. Sidhu, Y. In vitro micropropagation of medicinal plants by tissue culture. Plymouth Stud. Sci. 2010, 4, 432-449.

14. Khan, M.Y.; Aliabbas, S.; Kumar, V.; Rajkumar, S. Recent advances in medicinal plant biotechnology. Indian J. Biotechnol. 2009, 8 , 9-22.

15. Piątczak, E.; Grzegorczyk-Karolak, I.; Wysokińska, H. Micropropagation of Rehmannia glutinosa Libosch.: Production of phenolics and flavonoids and evaluation of antioxidant activity. Acta Physiol. Plant. 2014, 36, 1693-1702. [CrossRef]

16. Takayama, S.; Akita, M. The types of bioreactors used for shoots and embryos. Plant Cell Tissue Organ Cult. 1994, 39, 147-156. [CrossRef] 
17. Leathers, R.R.; Smith, M.A.L.; Aitken-Christie, J. Automation of the Bioreactor Process for Mass Propagation and Secondary Metabolism. In Automation and Environmental Control in Plant Tissue Culture; Aitken-Christie, J., Kozai, T., Smith, M.A.L., Eds.; Springer: Dordrecht, The Netherlands, 1995; pp. 187-214.

18. Chakrabarty, D.; Paek, K.Y. Recent Advances in In Vitro Manipulation and Propagation of Medicinal Plants, Proceedings of KSMCS International Symposium. 2001, pp. 26-61. Available online: https://kiss.kstudy.com/journal/journal-view.asp?key1=2 7476\&key2 $=8017$ (accessed on 20 November 2021).

19. Paek, K.Y.; Chakrabarty, D.; Hahn, E.J. Application of bioreactor systems for large scale production of horticultural and medicinal plants. Plant Cell Tissue Organ Cult. 2005, 81, 287-300. [CrossRef]

20. Mamun, N.H.A.; Egertsdotter, U.; Aidun, C.K. Bioreactor technology for clonal propagation of plants and metabolite production. Front. Biol. 2015, 10, 177-193. [CrossRef]

21. Krol, A.; Kokotkiewicz, A.; Szopa, A.; Ekiert, H.M.; Luczkiewicz, M. Bioreactor-Grown Shoot Cultures for the Secondary Metabolite Production. In Plant Cell and Tissue Differentiation and Secondary Metabolites; Ramawat, K.G., Ekiert, H.M., Goyal, S., Eds.; Springer: Cham, Switzerland, 2021; pp. 187-247.

22. Takayama, S.; Misawa, M. Mass propagation of Begonia $\times$ hiemalis plantlets by shake culture. Plant Cell Physiol. 1981, 22, 461-467.

23. Debnath, S.C. Bioreactors and molecular analysis in berry crop micropropagation-A review. Can. J. Plant Sci. 2011, 91, 147-157. [CrossRef]

24. Yaseen, M.; Ahmad, T.; Sablok, G.; Standardi, A.; Hafiz, I.A. Review: Role of carbon sources for in vitro plant growth and development. Mol. Biol. Rep. 2013, 40, 2837-2849. [CrossRef] [PubMed]

25. Dewir, Y.H.; Indoliya, Y.; Chakrabarty, D.; Paek, K.Y. Biochemical and physiological aspects of hyperhydricity in liquid culture system. In Production of Biomass and Bioactive Compounds Using Bioreactor Technology; Paek, K.Y., Murthy, H., Zhong, J.J., Eds.; Springer: Dordrecht, The Netherlands, 2014; pp. 693-709.

26. Berthouly, M.; Etienne, H. Temporary Immersion System: A New Concept for Use Liquid Medium in Mass Propagation. In Liquid Culture Systems for In Vitro Plant Propagation; Hvoslef-Eide, A.K., Preil, W., Eds.; Springer: Dordrecht, The Netherlands, 2005; pp. 165-195.

27. Harris, R.E.; Mason, E.B.B. Two machines for in vitro propagation of plants in liquid media. Can. J. Plant Sci. 1983, 63, 311-316. [CrossRef]

28. Etienne, H.; Berthouly, M. Temporary immersion systems in plant micropropagation. Plant Cell Tissue Organ Cult. 2002, 69, 215-231. [CrossRef]

29. Georgiev, V.; Schumann, A.; Pavlov, A.; Bley, T. Temporary immersion systems in plant biotechnology. Eng. Life Sci. 2014, 14, 607-621. [CrossRef]

30. Watt, P. The status of temporary inmersion system (TIS) technology for plant micropropagation. Afr. J. Biotechnol. 2012, 11, 14025-14035.

31. Wilken, D.; Jiménez Gonzalez, E.; Gerth, A.; Gómez-Kosky, R.; Schumann, A.; Claus, D. Effect of immersion systems, lighting, and TIS designs on biomass increase in micropropagating banana (Musa spp. cv. "Grande naine" AAA). In Vitro Cell. Dev. Biol.-Plant 2014, 50, 582-589. [CrossRef]

32. Akdemir, H.; Süzerer, V.; Onay, A.; Tilkat, E.; Ersali, Y.; Çiftçi, Y.O. Micropropagation of the pistachio and its rootstocks by temporary immersion system. Plant Cell Tissue Organ Cult. 2014, 117, 65-76. [CrossRef]

33. Carvalho, L.S.O.; Ozudogru, E.A.; Lambardi, M.; Paiva, L.V. Temporary immersion system for micropropagation of tree species: A bibliographic and systematic review. Not. Bot. Horti Agrobot. Cluj-Napoca 2019, 47, 269-277. [CrossRef]

34. Steingroewer, J.; Bley, T.; Georgiev, V.; Ivanov, I.; Lenk, F.; Marchev, A.; Pavlov, A. Bioprocessing of differentiated plant in vitro systems. Eng. Life Sci. 2013, 13, 26-38. [CrossRef]

35. Yancheva, S.; Georgieva, L.; Badjakov, I.; Dincheva, I.; Georgieva, M.; Georgiev, V.; Kondakova, V. Application of bioreactor technology in plant propagation and secondary metabolite production. J. Cent. Eur. Agric. 2019, 20, 321-340. [CrossRef]

36. Debergh, P.; Aitken-Christie, J.; Cohen, D.; Grout, B.; von Arnold, S.; Zimmerman, R.; Ziv, M. Reconsideration of the term 'vitrification' as used in micropropagation. Plant Cell Tissue Organ Cult. 1992, 30, 135-140. [CrossRef]

37. Gaspar, T. Vitrification in Micropropagation. In High-Tech and Micropropagation I. Biotechnology in Agriculture and Forestry; Bajaj, Y.P.S., Ed.; Springer: Berlin, Heidelberg, 1991; Volume 17, pp. 116-126.

38. Ziv, M. Vitrification: Morphological and physiological Disorders of In Vitro Plants. In Micropropagation; Springer: Dordrecht, The Netherlands, 1991; pp. 45-69.

39. Rojas-Martínez, L.; Visser, R.G.F.; de Klerk, G.J. The hyperhydricity syndrome: Waterlogging of plant tissues as a major cause. Propag. Ornam. Plants 2010, 10, 169-175.

40. Vidensek, N.; Lim, P.; Campbell, A.; Carlson, C. Taxol content in bark, wood, root, leaf, twig, and seedling from several taxus species. J. Nat. Prod. 1990, 53, 1609-1610. [CrossRef]

41. Zobayed, S.M.A.; Saxena, P.K. In vitro-grown roots: A superior explant for prolific shoot regeneration of St. John's wort (Hypericum perforatum L. cv 'New Stem') in a temporary immersion bioreactor. Plant Sci. 2003, 165, 463-470. [CrossRef]

42. Kaya, E.; Galatali, S.; Guldag, S.; Ozturk, B.; Ceylan, M.; Celik, O.; Aktay, I. Mass production of medicinal plants for obtaining secondary metabolite using liquid mediums via bioreactor systems: SETIS ${ }^{\mathrm{TM}}$ and RITA $^{\circledR}$. Derleme 2018, 11, 5-10. 
43. Schmeda-Hirschmann, G.; Jordan, M.; Gerth, A.; Wilken, D.; Hormazabal, E.; Tapia, A.A. Secondary metabolite content in Fabiana imbricata plants and in vitro cultures. Z. Naturforsch. -Sect. C J. Biosci. 2004, 59, 48-54. [CrossRef]

44. Yoon, Y.J.; Murthy, H.N.; Eun, J.H.; Kee, Y.P. Biomass production of Anoectochilus formosanus Hayata in a bioreactor system. J. Plant Biol. 2007, 50, 573-576. [CrossRef]

45. Ruffoni, B.; Savona, M. The temporary immersion system (T.I.S.) for the improvement of micropropagation of ornamental plants Acta Hortic. 2005, 683, 445-454. [CrossRef]

46. Ramírez-Mosqueda, M.A.; Cruz-Cruz, C.A.; Cano-Ricárdez, A.; Bello-Bello, J.J. Assessment of different temporary immersion systems in the micropropagation of anthurium (Anthurium andreanum). 3 Biotech 2019, 9, 307. [CrossRef]

47. Martínez-Estrada, E.; Islas-Luna, B.; Pérez-Sato, J.A.; Bello-Bello, J.J. Temporary immersion improves in vitro multiplication and acclimatization of Anthurium andreanum Lind. Sci. Hortic. 2019, 249, 185-191. [CrossRef]

48. Esyanti, R.R.; Fadholi, M.; Rizki, R.M.; Faizal, A. Shoot multiplication and growth rates of Aquilaria malaccensis Lamk. shoot cultures in temporary immersion system (TIS)-RITA ${ }^{\circledR}$ and bubble column bioreactors. Pak. J. Bot. 2019, 51, 1317-1321. [CrossRef]

49. Trentini, G.E.; Rojas, M.; Gajardo, D.; Alburquenque, D.; Villagra, E.; Gómez, A.; Arru, L.; Arencibia, A.D. Elicitation of phenylpropanoids in maqui (Aristotelia chilensis [Mol.] Stuntz) plants micropropagated in photomixotrophic temporary immersion bioreactors (TIBs). Plant Cell Tissue Organ Cult. 2021, 146, 607-619. [CrossRef]

50. Liu, C.Z.; Murch, S.J.; El-Demerdash, M.; Saxena, P.K. Artemisia judaica L.: Micropropagation and antioxidant activity. J. Biotechnol. 2004, 110, 63-71. [CrossRef]

51. García-Ramírez, Y.; Barrera, G.P.; Freire-Seijo, M.; Barbón, R.; Concepción-Hernández, M.; Mendoza-Rodríguez, M.F.; Torres-García, S. Effect of sucrose on physiological and biochemical changes of proliferated shoots of Bambusa vulgaris Schrad. Ex Wendl in temporary immersion. Plant Cell Tissue Organ Cult. 2019, 137, 239-247. [CrossRef]

52. Zhang, B.; Sarsaiya, S.; Pan, X.; Jin, L.; Xu, D.; Zhang, B.; Duns, G.J.; Shi, J.; Chen, J. Optimization of nutritional conditions using a temporary immersion bioreactor system for the growth of Bletilla striata pseudobulbs and accumulation of polysaccharides. Sci. Hortic. 2018, 240, 155-161. [CrossRef]

53. Yang, S.H.; Yeh, D.M. In vitro leaf anatomy, ex vitro photosynthetic behaviors and growth of Calathea orbifolia (Linden) Kennedy plants obtained from semi-solid medium and temporary immersion systems. Plant Cell Tissue Organ Cult. 2008, 93, $201-207$. [CrossRef]

54. Gianguzzi, V.; Inglese, P.; Barone, E.; Sottile, F. In vitro regeneration of Capparis spinosa L. by using a temporary immersion system. Plants 2019, 8, 177. [CrossRef] [PubMed]

55. Moreira, A.L.; da Silva, A.B.; Santos, A.; dos Reis, C.O.; Landgraf, P.R.C. Crescimento de Cattleya walkeriana em diferentes sistemas de micropropagação. Cienc. Rural 2013, 43, 1804-1810. [CrossRef]

56. Wawrosch, C.; Kongbangkerd, A.; Köpf, A.; Kopp, B. Shoot regeneration from nodules of Charybdis sp.: A comparison of semisolid, liquid and temporary immersion culture systems. In Liquid Culture Systems for In Vitro Plant Propagation; Hvoslef-Eide, A.K., Preil, W., Eds.; Springer: Dordrecht, The Netherlands, 2005; pp. 275-280.

57. Mancilla-álvarez, E.; Pérez-Sato, J.A.; Núñez-Pastrana, R.; Spinoso-Castillo, J.L.; Bello-Bello, J.J. Comparison of different semiautomated bioreactors for in vitro propagation of taro (Colocasia esculenta L. Schott). Plants 2021, 10, 1010. [CrossRef] [PubMed]

58. Murch, S.J.; Liu, C.; Romero, R.M.; Saxena, P.K. In Vitro culture and temporary immersion bioreactor production of Crescentia cujete. Plant Cell Tissue Organ Cult. 2004, 78, 63-68. [CrossRef]

59. Quiala, E.; Barbón, R.; Jiménez, E.; De Feria, M.; Chávez, M.; Capote, A.; Pérez, N. Biomass production of Cymbopogon citratus (D.C.) Stapf., a medicinal plant, in temporary immersion systems. In Vitro Cell. Dev. Biol. -Plant 2006, 42, 298-300. [CrossRef]

60. Quiala, E.; Barbón, R.; Capote, A.; Pérez, N.; Jiménez, E. In Vitro Mass Propagation of Cymbopogon citratus Stapf., A medicinal Gramineae. In Methods in Molecular Biology; Humana Press: New York, NY, USA, 2016; Volume 1391.

61. Marchant, M.J.; Molina, P.; Montecinos, M.; Guzmán, L.; Balada, C.; Fassio, C.; Castro, M. In vitro propagation of Easter Island Curcuma longa from rhizome explants using temporary immersion system. Agronomy 2021, 11, 2121. [CrossRef]

62. Stanly, C.; Bhatt, A.; Keng, C.L. A comparative study of Curcuma zedoaria and Zingiber zerumbet plantlet production using different micropropagation systems. Afr. J. Biotechnol. 2010, 9, 4326-4333. [CrossRef]

63. Ahmadian, M.; Babaei, A.; Shokri, S.; Hessami, S. Micropropagation of carnation (Dianthus caryophyllus L.) in liquid medium by temporary immersion bioreactor in comparison with solid culture. J. Genet. Eng. Biotechnol. 2017, 15, 309-315. [CrossRef] [PubMed]

64. Thi, L.T.; Park, Y.G.; Jeong, B.R. Growth and development of carnation 'Dreambyul' plantlets in a temporary immersion system and comparisons with conventional solid culture methods. In Vitro Cell. Dev. Biol. -Plant 2019, 55, 539-548. [CrossRef]

65. Pérez-Alonso, N.; Capote, A.; Pérez, A.; Gerth, A.; Chong-Pérez, B.; Jiménez, E. Efecto de la densidad de inóculo y la renovación de la atmósfera gaseosa en el cultivo de brotes de Digitalis purpurea L. en Sistemas de Inmersión Temporal. Biotecnol. Veg. 2015, 15, 35-45.

66. Pérez-Alonso, N.; Chong-Pérez, B.; Capote, A.; Pérez, A.; Gerth, A.; Angenon, G.; Jiménez, E. Biotechnological Approaches for Biomass and Cardenolide Production in Digitalis purpurea L. In Methods in Molecular Biology; Humana Press: New York, NY, USA, 2016; Volume 1391, pp. 81-102.

67. Yan, H.; Yang, L.; Li, Y. Improved growth and quality of Dioscorea fordii Prain et Burk and Dioscorea alata plantlets using a temporary immersion system. Afr. J. Biotechnol. 2011, 10, 19444-19448. [CrossRef] 
68. Lata, H.; Bedir, E.; Moraes, R.M.; Andrade, Z. Mass Propagation of Echinacea Angustifolia: A Protocol Refinement Using Shoot Encapsulation and Temporary Immersion Liquid System. In Proceedings of the Acta Horticulturae; Canadian International Development Agency: Toronto, Canada, 2004; Volume 629.

69. Kunakhonnuruk, B.; Inthima, P.; Kongbangkerd, A. In vitro propagation of rheophytic orchid, Epipactis flava Seidenf.-A comparison of semi-solid, continuous immersion and temporary immersion systems. Biology 2019, 8, 72. [CrossRef]

70. Souza, D.M.S.C.; Avelar, M.L.M.; Fernandes, S.B.; Silva, E.O.; Duarte, V.P.; Molinari, L.V.; Brondani, G.E. Spectral quality and temporary immersion bioreactor for in vitro multiplication of Eucalytpus grandis $\times$ Eucalyptus urophylla. 3 Biotech 2020, 10, 457 . [CrossRef]

71. Mohd, N.M.; Ja'afar, H.; Zawawi, D.D.; Alias, N. In vitro somatic embryos multiplication of Eurycoma longifolia Jack using temporary immersion system RITA $^{\circledR}$. Sains Malays. 2017, 46, 897-902. [CrossRef]

72. Wawrosch, C. Temporary Immersion Systems for Efficient Mass Propagation of Medicinal and Aromatic Plants. In Proceedings of the Acta Horticulturae; ISHS: Angers, France, 2015; Volume 1099.

73. Manuhara, Y.S.W.; Kusuma, D.Y.; Sari, R.L.K.; Kristanti, A.N. Biomass production of Gynura procumbens adventitious roots in different type of liquid culture. Biosaintifika J. Biol. Biol. Educ. 2017, 9, 523. [CrossRef]

74. Martre, P.; Lacan, D.; Just, D.; Teisson, C. Physiological effects of temporary immersion on Hevea brasiliensis callus. Plant Cell Tissue Organ Cult. 2001, 67, 25-35. [CrossRef]

75. Ilczuk, A.; Winkelmann, T.; Richartz, S.; Witomska, M.; Serek, M. In vitro propagation of Hippeastrum $\times$ chmielii Chm.-Influence of flurprimidol and the culture in solid or liquid medium and in temporary immersion systems. Plant Cell Tissue Organ Cult. 2005, 83, 339-346. [CrossRef]

76. Be, N.; Zhu, L. Developing an in vitro propagation method for mass production of medicinal Hypoxis species using bioreactors. Asian J. Plant Sci. Res. 2017, 7, 1-8.

77. Malosso, M.G.; Bertoni, B.W.; da Silva Coppede, J.; de Castro Franca, S.; Pereira, A.M.S. Micropropagation and in vitro conservation of Jacaranda decurrens Cham. J. Med. Plants Res. 2012, 6, 1147-1154. [CrossRef]

78. Jeong, B.R.; Sivanesan, I. Micropropagation, berberine content and antitumor activity of Jeffersonia dubia (Maxim.) Benth et Hook. Plant Cell Tissue Organ Cult. 2016, 124, 453-458. [CrossRef]

79. Shaik, S.; Dewir, Y.H.; Singh, N.; Nicholas, A. Micropropagation and bioreactor studies of the medicinally important plant Lessertia (Sutherlandia) frutescens L. S. Afr. J. Bot. 2010, 76, 180-186. [CrossRef]

80. Ptak, A. Leucojum aestivum L. in vitro bulbs induction and acclimatization. Cent. Eur. J. Biol. 2014, 9, 1011-1021. [CrossRef]

81. Jiménez, E.; Reyes, C.; Machado, P.; Pérez-Alonso, N.; Capote, A.; Pérez, A.; Eichler-Loebermann, B. Multiplicación in vitro de Morinda royoc L. en Sistemas de Inmersión Temporal. Biotecnol. Veg. 2011, 11, 115-118.

82. De Carlo, A.; Cencetti, G.; Michelozzi, M. Impiego dell'innovativo bioreattore "Plantform" ad immersione temporanea per la coltura in vitro di Myrtus communis e per la produzione di metaboliti secondari. Acta Italus Hortus 2013, 12, 146.

83. Kaçar, Y.A.; Biçen, B.; Şimşek, Ö.; Dönmez, D.; Erol, M.H. Evaluation and comparison of a new type of temporary immersion system (TIS) bioreactors for myrtle (Myrtus communis L.). Appl. Ecol. Environ. Res. 2020, 18, 1611-1620. [CrossRef]

84. Benelli, C.; De Carlo, A. In vitro multiplication and growth improvement of Olea europaea L. cv Canino with temporary immersion system (Plantform ${ }^{\mathrm{TM}}$ ). 3 Biotech 2018, 8, 1-5. [CrossRef]

85. Välimäki, S.; Paavilainen, L.; Tikkinen, M.; Salonen, F.; Varis, S.; Aronen, T. Production of Norway spruce embryos in a temporary immersion system (TIS). In Vitro Cell. Dev. Biol.-Plant 2020, 56, 430-439. [CrossRef]

86. Jia, M.L.; Zhang, B.H.; Gao, W.P.; Chen, J.S.; Ouyang, P. Micropropagation of Pinellia Ternata (Thunb.) Breit in a bioreactor using temporary immersion system. China Biotechnol. 2012, 32, 49-54.

87. De Sousa, P.C.A.; Souza, S.S.S.E.; Meira, F.S.; Meira, R.D.O.; Gomes, H.T.; Silva-Cardoso, I.M.D.A.; Scherwinski-Pereira, J.E. Somatic embryogenesis and plant regeneration in Piper aduncum L. In Vitro Cell. Dev. Biol. -Plant 2020, 56, 618-633. [CrossRef]

88. Meimand, M.J.M.; Ruffoni, B.; Mascarello, C.; Shamshiri, M.H.; Malekzadeh, K. Micropropagation of Pistacia lentiscus L.Optimization of the surface sterilization protocol and forced ventilation in temporary immersion culture. Fruit Grow. Res. 2020, 36, 75-82. [CrossRef]

89. Vilchez, J.; Albany, N. Multiplicación in vitro de Psidium guajava L. en sistemas de inmersión temporal In vitro multiplication of Psidium guajava L. in temporary immersion systems. Rev. Colomb. Biotecnol. Diciembre 2014, 16, 96-103. [CrossRef]

90. Gatti, E.; Sgarbi, E.; Ozudogru, E.A.; Lambardi, M. The effect of PlantformTM bioreactor on micropropagation of Quercus robur in comparison to a conventional in vitro culture system on gelled medium, and assessment of the microenvironment influence on leaf structure. Plant Biosyst. 2017, 151, 1129-1136. [CrossRef]

91. Debnath, S.C. Zeatin and TDZ-induced shoot proliferation and use of bioreactor in clonal propagation of medicinal herb, roseroot (Rhodiola rosea L). J. Plant Biochem. Biotechnol. 2009, 18, 245-248. [CrossRef]

92. Yan, H.; Liang, C.; Li, Y. Improved growth and quality of Siraitia grosvenorii plantlets using a temporary immersion system. Plant Cell Tissue Organ Cult. 2010, 103, 131-135. [CrossRef]

93. Alvarenga-Venutolo, S.; Salazar-Aguilar, T. Micropropagación masiva de Stevia Rebaudiana Bertoni en sistemas de inmersión temporal. Rev. Cultiv. Trop. 2015, 36, 50-57.

94. Sacco, E.; Mascarello, C.; Pamato, M.; Musso, V.; Ruffoni, B. Evaluation of Temporary Immersion System for in vitro propagation of Stevia rebaudiana Bertoni. Acta Hortic. 2015, 1083, 327-333. [CrossRef] 


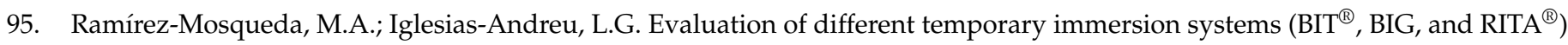
in the micropropagation of Vanilla planifolia Jacks. In Vitro Cell. Dev. Biol. -Plant 2016, 52, 154-160. [CrossRef]

96. Rosales, C.; Brenes, J.; Salas, K.; Arce-Solano, S.; Abdelnour-Esquivel, A. Micropropagación de Stevia rebaudiana en sistemas de inmersión temporal para incursionar en la producción hortícola. Rev. Chapingo Ser. Hortic. 2018, 24, 69-84. [CrossRef]

97. Bayraktar, M. Micropropagation of Stevia rebaudiana Bertoni using RITA ${ }^{\circledR}$ bioreactor. HortScience 2019, 54, 725-731. [CrossRef]

98. Kumar, A.; Kaushal, S.; Sharma, S.; Sood, H.; Sharma, D.R. Novel method of bioreactor to propagate Swertia chirayita: A critically endangered medicinal plant. Wkly. Sci. Res. J. 2013, 1, 7-8. [CrossRef]

99. Peña-Rojas, G.; Carhuaz-Condori, R.; Andía-Ayme, V.; Dávalos-Prado, J.Z. Use of RITA ${ }^{\circledR}$ temporary immersion system to obtain microtubers of several mashua (Tropaeolum tuberosum Ruiz \& Pavón) morphotypes. Trop. Subtrop. Agroecosystems 2020, 23, 1-10.

100. Arencibia, A.D.; Vergara, C.; Quiroz, K.; Carrasco, B.; Bravo, C.; Garcia-Gonzales, R. An approach for micropropagation of blueberry (Vaccinium corymbosum L.) plants mediated by Temporary Immersion Bioreactors (TIBs). Am. J. Plant Sci. 2013, 4, 1022-1028. [CrossRef]

101. Ramos-Castellá, A.; Iglesias-Andreu, L.G.; Bello-Bello, J.J.; Lee-Espinosa, H. Improved propagation of vanilla (Vanilla planifolia Jacks. ex Andrews) using a temporary immersion system. In Vitro Cell. Dev. Biol. -Plant 2014, 50, 576-581. [CrossRef]

102. Spinoso-Castillo, J.L.; Chavez-Santoscoy, R.A.; Bogdanchikova, N.; Pérez-Sato, J.A.; Morales-Ramos, V.; Bello-Bello, J.J. Antimicrobial and hormetic effects of silver nanoparticles on in vitro regeneration of vanilla (Vanilla planifolia Jacks. ex Andrews) using a temporary immersion system. Plant Cell Tissue Organ Cult. 2017, 129, 195-207. [CrossRef]

103. Ramírez-Mosqueda, M.A.; Bello-Bello, J.J. SETIS ${ }^{\mathrm{TM}}$ bioreactor increases in vitro multiplication and shoot length in vanilla (Vanilla planifolia Jacks. Ex Andrews). Acta Physiol. Plant. 2021, 43, 1-8. [CrossRef]

104. Hempfling, T.; Preil, W. Application of a Temporary Immersion System in Mass Propagation of Phalaenopsis. In Liquid Culture Systems for In Vitro Plant Propagation; Hvoslef-Eide, A.K., Preil, W., Eds.; Springer: Dordrecht, The Netherlands, 2005; pp. 231-242. [CrossRef]

105. Petrova, M.; Zayova, E.; Todorova, M.; Stanilova, M. Enhancement of Arnica montana in-vitro shoot multiplication and sesquiterpene lactones production using temporary immersion system. Int. J. Pharm. Sci. Res. 2014, 5, 5170-5176.

106. Sankar-Thomas, Y.D.; Lieberei, R. Camptothecin accumulation in various organ cultures of Camptotheca acuminata Decne grown in different culture systems. Plant Cell Tissue Organ Cult. 2011, 106, 445-454. [CrossRef]

107. Ruta, C.; De Mastro, G.; Ancona, S.; Tagarelli, A.; De Cillis, F.; Benelli, C.; Lambardi, M. Large-scale plant production of Lycium barbarum L. by liquid culture in temporary immersion system and possible application to the synthesis of bioactive substance. Plants 2020, 9, 844. [CrossRef] [PubMed]

108. Malik, M.; Warchoł, M.; Kwaśniewska, E.; Pawłowska, B. Biochemical and morphometric analysis of Rosa tomentosa and Rosa rubiginosa during application of liquid culture systems for in vitro shoot production. J. Hortic. Sci. Biotechnol. 2017, 92, 606-613. [CrossRef]

109. Wilken, D.; González, E.J.; Hohe, A.; Jordan, M.; Gomez Kosky, R.; Schmeda Hirschmann, G.; Gerth, A. Comparison of Secondary Plant Metabolite Production in Cell Suspension, Callus Culture and Temporary Immersion System. In Liquid Culture Systems for In Vitro Plant Propagation; Hvoslef-Eide, A.K., Preil, W., Eds.; Springer: Dordrecht, The Netherlands, 2005; pp. 525-537. [CrossRef]

110. Zobayed, S.M.A.; Murch, S.J.; Rupasinghe, H.P.V.; De Boer, J.G.; Glickman, B.W.; Saxena, P.K. Optimized system for biomass production, chemical characterization and evaluation of chemo-preventive properties of Scutellaria baicalensis Georgi. Plant Sci. 2004, 167, 439-446. [CrossRef]

111. Vives, K.; Andújar, I.; Lorenzo, J.C.; Concepción, O.; Hernández, M.; Escalona, M. Comparison of different in vitro micropropagation methods of Stevia rebaudiana B. including temporary immersion bioreactor (BIT ${ }^{\circledR}$ ). Plant Cell Tissue Organ Cult. 2017, 131, 195-199. [CrossRef]

112. Arigundam, U.; Variyath, A.M.; Siow, Y.L.; Marshall, D.; Debnath, S.C. Liquid culture for efficient in vitro propagation of adventitious shoots in wild Vaccinium vitis-idaea ssp. minus (lingonberry) using temporary immersion and stationary bioreactors. Sci. Hortic. 2020, 264, 109199. [CrossRef]

113. Phuc, V.T.; Trung, N.M.; Thien, H.T.; Tien, L.T.T. Proliferation and ajmalicine biosynthesis of Catharanthus roseus (L). G. Don adventitious roots in self-built temporary immersion system. In Proceedings of the AIP Conference Proceedings, Ho Chi Minh City, Vietnam, 12-13 October 2017; Volume 1878.

114. Leveille, G.; Rai, D.; Cahill, E.; Caffrey, E.; Tennyson, E.; Wilson, G. Application of the temporary immersion system for the in vitro production of bioactive compounds in harpagophytum (Devil's claw). Acta Hortic. 2006, 725, 597-604. [CrossRef]

115. Jesionek, A.; Kokotkiewicz, A.; Wlodarska, P.; Zabiegala, B.; Bucinski, A.; Luczkiewicz, M. Bioreactor shoot cultures of Rhododendron tomentosum (Ledum palustre) for a large-scale production of bioactive volatile compounds. Plant Cell Tissue Organ Cult. 2017, 131, 51-64. [CrossRef]

116. Mišić, D.; Šiler, B.; Skorić, M.; Djurickovic, M.S.; Nestorović Živković, J.; Jovanović, V.; Giba, Z. Secoiridoid glycosides production by Centaurium maritimum (L.) Fritch hairy root cultures in temporary immersion bioreactor. Process Biochem. 2013, 48, 1587-1591. [CrossRef]

117. Pavlov, A.; Bley, T. Betalains biosynthesis by Beta vulgaris L. hairy root culture in a temporary immersion cultivation system. Process Biochem. 2006, 41, 848-852. [CrossRef] 
118. Valdez-Tapia, R.; Capataz-Tafur, J.; López-Laredo, A.R.; Trejo-Espino, J.L.; Trejo-Tapia, G. Effect of immersion cycles on growth, phenolics content, and antioxidant properties of Castilleja tenuiflora shoots. In Vitro Cell. Dev. Biol. -Plant 2014, 50, 471-477. [CrossRef]

119. Medina-Pérez, V.; López-Laredo, A.R.; Sepúlveda-Jiménez, G.; Zamilpa, A.; Trejo-Tapia, G. Nitrogen deficiency stimulates biosynthesis of bioactive phenylethanoid glycosides in the medicinal plant Castilleja tenuiflora Benth. Acta Physiol. Plant. 2015, 37, 1-8. [CrossRef]

120. Skrzypczak-Pietraszek, E.; Urbańska, A.; Żmudzki, P.; Pietraszek, J. Elicitation with methyl jasmonate combined with cultivation in the Plantform ${ }^{\mathrm{TM}}$ temporary immersion bioreactor highly increases the accumulation of selected centellosides and phenolics in Centella asiatica (L.) Urban shoot culture. Eng. Life Sci. 2019, 19, 931-943. [CrossRef] [PubMed]

121. Ashraf, M.F.; Aziz, M.A.; Stanslas, J.; Kadir, M.A. Optimization of immersion frequency and medium substitution on microtuberization of Chlorophytum borivilianum in RITA system on production of saponins. Process Biochem. 2013, $48,73-77$. [CrossRef]

122. Pérez-Alonso, N.; Capote, A.; Gerth, A.; Jiménez, E. Increased cardenolides production by elicitation of Digitalis lanata shoots cultured in temporary immersion systems. Plant Cell Tissue Organ Cult. 2012, 110, 153-162. [CrossRef]

123. Pérez-Alonso, N.; Wilken, D.; Gerth, A.; Jähn, A.; Nitzsche, H.M.; Kerns, G.; Capote-Perez, A.; Jiménez, E. Cardiotonic glycosides from biomass of Digitalis purpurea L. cultured in temporary immersion systems. Plant Cell Tissue Organ Cult. 2009, 99, 151-156. [CrossRef]

124. Weremczuk-Jezyna, I.; Lisiecki, P.; Gonciarz, W.; Kuzma, Ł.; Szemraj, M.; Chmiela, M.; Grzegorczyk-Karolak, I. Transformed shoots of Dracocephalum forrestii W.W. smith from different bioreactor systems as a rich source of natural phenolic compounds. Molecules 2020, 25, 4533. [CrossRef]

125. Pramita, A.D.; Kristanti, A.N.; Utami, E.S.W.; Manuhara, Y.S.W. Production of biomass and flavonoid of Gynura procumbens (Lour.) Merr shoots culture in temporary immersion system. J. Genet. Eng. Biotechnol. 2018, 16, 639-643. [CrossRef]

126. Schumann, A.; Torras-Claveria, L.; Berkov, S.; Claus, D.; Gerth, A.; Bastida, J.; Codina, C. Elicitation of galanthamine production by Leucojum aestivum shoots grown in temporary immersion system. Biotechnol. Prog. 2013, 29, 311-318. [CrossRef]

127. Ivanov, I.; Georgiev, V.; Georgiev, M.; Ilieva, M.; Pavlov, A. Galanthamine and related alkaloids production by Leucojum aestivum L. shoot culture using a temporary immersion technology. Appl. Biochem. Biotechnol. 2011, 163, 268-277. [CrossRef]

128. Klimek-Szczykutowicz, M.; Dziurka, M.; Blažević, I.; Đulović, A.; Granica, S.; Korona-Glowniak, I.; Ekiert, H.; Szopa, A. Phytochemical and biological activity studies on Nasturtium officinale (Watercress) microshoot cultures grown in RITA ${ }^{\circledR}$ temporary immersion systems. Molecules 2020, 25, 5257. [CrossRef]

129. Langhansova, L.; Marsik, P.; Vanek, T. Regulation of tissue differentiation by plant growth regulators on tTCLs of Panax ginseng adventitious roots. Ind. Crops Prod. 2012, 35, 154-159. [CrossRef]

130. Vaněk, T.; Langhansová, L.; Maršĺk, P. Cultivation of Root Cultures of Panax Ginseng in Different Bioreactors and in Temporary Immersion-Comparison of Growth and Saponin Production. In Liquid Culture Systems for In Vitro Plant Propagation; Hvoslef-Eide, A.K., Preil, W., Eds.; Springer: Dordrecht, The Netherlands, 2005; pp. 539-546.

131. Georgiev, V.; Ivanov, I.; Berkov, S.; Pavlov, A. Temporary immersion systems for Amaryllidaceae alkaloids biosynthesis by Pancratium maritimum L. shoot culture. J. Plant Biochem. Biotechnol. 2014, 23, 389-398. [CrossRef]

132. Malik, M.; Warchoł, M.; Pawłowska, B. Liquid culture systems affect morphological and biochemical parameters during Rosa canina plantlets in vitro production. Not. Bot. Horti Agrobot. Cluj-Napoca 2018, 46, 58-64. [CrossRef]

133. Jang, H.-R.; Lee, H.-J.; Shohael, A.M.; Park, B.-J.; Paek, K.-Y.; Park, S.-Y. Production of biomass and bioactive compounds from shoot cultures of Rosa rugosa using a bioreactor culture system. Hortic. Environ. Biotechnol. 2016, 57, 79-87. [CrossRef]

134. Grzegorczyk-Karolak, I.; Staniewska, P.; Lebelt, L.; Piotrowska, D.G. Optimization of cultivation conditions of Salvia viridis L. shoots in the Plantform bioreactor to increase polyphenol production. Plant Cell Tissue Organ Cult. 2021, 1-12. [CrossRef]

135. Szopa, A.; Kokotkiewicz, A.; Luczkiewicz, M.; Ekiert, H. Schisandra lignans production regulated by different bioreactor type. J. Biotechnol. 2017, 247, 11-17. [CrossRef]

136. Szopa, A.; Kokotkiewicz, A.; Bednarz, M.; Jafernik, K.; Luczkiewicz, M.; Ekiert, H. Bioreactor type affects the accumulation of phenolic acids and flavonoids in microshoot cultures of Schisandra chinensis (Turcz.) Baill. Plant Cell Tissue Organ Cult. 2019, 139, 199-206. [CrossRef]

137. López, C.Q.; Corral, P.; Lorrain-Lorrette, B.; Martinez-Swatson, K.; Michoux, F.; Simonsen, H.T. Use of a temporary immersion bioreactor system for the sustainable production of thapsigargin in shoot cultures of Thapsia garganica. Plant Methods 2018, 14, 79. [CrossRef]

138. Radović, M.; Šiler, B.; Živković, J.N.; Banjanac, T.; Živković, S.; Nikolić, M.; Soković, M.; Mišić, D. Bioreactor cultivation of Zeltnera beyrichii (Torr. \& A. Gray) Mans.: A novel source of biologically active compounds. Rec. Nat. Prod. 2013, 7, $266-280$.

139. Pérez, M.; Bueno, M.A.; Escalona, M.; Toorop, P.; Rodríguez, R.; Cañal, M.J. Temporary immersion systems (RITA®) for the improvement of cork oak somatic embryogenic culture proliferation and somatic embryo production. Trees -Struct. Funct. 2013, 27, 1277-1284. [CrossRef]

140. Escalona, M.; Lorenzo, J.C.; González, B.; Daquinta, M.; González, J.L.; Desjardins, Y.; Borroto, C.G. Pineapple (Ananas comosus L. Merr) micropropagation in temporary immersion systems. Plant Cell Rep. 1999, 18, 743-748. [CrossRef]

141. Bello-Bello, J.J.; Cruz-Cruz, C.A.; Pérez-Guerra, J.C. A new temporary immersion system for commercial micropropagation of banana (Musa AAA cv. Grand Naine). In Vitro Cell. Dev. Biol. -Plant 2019, 55, 313-320. [CrossRef] 
142. Da Silva, J.A.; Solis-Gracia, N.; Jifon, J.; Souza, S.C.; Mandadi, K.K. Use of bioreactors for large-scale multiplication of sugarcane (Saccharum spp.), energy cane (Saccharum spp.), and related species. In Vitro Cell. Dev. Biol. -Plant 2020, 56, 366-376. [CrossRef]

143. Lotfi, M.; Bayoudh, C.; Werbrouck, S.; Mars, M. Effects of meta-topolin derivatives and temporary immersion on hyperhydricity and in vitro shoot proliferation in Pyrus communis. Plant Cell Tissue Organ Cult. 2020, 143, 499-505. [CrossRef]

144. Silva, S.T.; Bertolucci, S.K.V.; da Cunha, S.H.B.; Lazzarini, L.E.S.; Tavares, M.C.; Pinto, J.E.B.P. Effect of light and natural ventilation systems on the growth parameters and carvacrol content in the in vitro cultures of Plectranthus amboinicus (Lour.) Spreng. Plant Cell Tissue Organ Cult. 2017, 129, 501-510. [CrossRef]

145. Aragón, C.E.; Sánchez, C.; Gonzalez-Olmedo, J.; Escalona, M.; Carvalho, L.; Amâncio, S. Comparison of plantain plantlets propagated in temporary immersion bioreactors and gelled medium during in vitro growth and acclimatization. Biol. Plant. 2014, 58, 29-38. [CrossRef]

146. Liu, C.Z.; Guo, C.; Wang, Y.C.; Ouyang, F. Comparison of various bioreactors on growth and artemisinin biosynthesis of Artemisia annua L. shoot cultures. Process Biochem. 2003, 39, 45-49. [CrossRef]

147. Young, I.S.; Woodside, J.V. Antioxidants in health and disease. J. Clin. Pathol. 2001, 54, 176-186. [CrossRef]

148. Krishnaiah, D.; Sarbatly, R.; Nithyanandam, R. A review of the antioxidant potential of medicinal plant species. Food Bioprod. Process. 2011, 89, 217-233. [CrossRef]

149. Zhang, H.; Tsao, R. Dietary polyphenols, oxidative stress and antioxidant and anti-inflammatory effects. Curr. Opin. Food Sci. 2016, 8, 33-42. [CrossRef]

150. Roleira, F.M.F.; Tavares-Da-Silva, E.J.; Varela, C.L.; Costa, S.C.; Silva, T.; Garrido, J.; Borges, F. Plant derived and dietary phenolic antioxidants: Anticancer properties. Food Chem. 2015, 183, 235-258. [CrossRef]

151. Petersen, M. Rosmarinic acid. Phytochemistry 2003, 62, 121-125. [CrossRef]

152. Jova, M.C.; Kosky, R.G.; Morales, S.R.; Torres, J.L.; Cabrera, A.R.; Pérez, M.B.; Pino, A.S.; Vega, V.M.; Rodríguez, G.R. Blanco de Guinea (Dioscorea cayenensis-D. rotundata) yam clone in vitro nodal segment multiplication in a temporary immersion system. Rev. Colomb. Biotecnol. 2008, 10, 97-103.

153. Preil, W. General introduction: A personal reflection on the use of liquid media for in vitro culture. In Liquid Culture Systems for In Vitro Plant Propagation; Hvoslef-Eide, A.K., Preil, W., Eds.; Springer: Dordrecht, The Netherlands, 2005; pp. 1-18.

154. Gamborg, O.L.; Miller, R.A.; Ojima, K. Nutrient requirements of suspension cultures of soybean root cells. Exp. Cell Res. 1968, 50, 151-158. [CrossRef] 